\title{
Evaluation of balloon and satellite water vapour measurements in the Southern tropical and subtropical UTLS during the HIBISCUS campaign
}

\author{
N. Montoux ${ }^{1,2}$, A. Hauchecorne ${ }^{1}$, J.-P. Pommereau ${ }^{1}$, F. Lefèvre ${ }^{1}$, G. Durry ${ }^{1,3}$, R. L. Jones ${ }^{4}$, A. Rozanov ${ }^{5}$, S. Dhomse ${ }^{5, *}$, \\ J. P. Burrows ${ }^{5}$, B. Morel $^{2}$, and H. Bencherif ${ }^{2}$ \\ ${ }^{1}$ Laboratoire atmosphères, milieux, observations spatiales, Université Paris VI, CNRS, Verrières-le-Buisson, France \\ ${ }^{2}$ Laboratoire de l'Atmosphère et des Cyclones, Université de la Réunion, CNRS, St-Denis de la Réunion, France \\ ${ }^{3}$ Groupe de Spectroscopie moléculaire et Atmosphérique, Université de Reims Champagne-Ardenne, CNRS, Reims, France \\ ${ }^{4}$ Center for Atmospheric Science, University Chemical Laboratory, University of Cambridge, Cambridge, UK \\ ${ }^{5}$ Institute of Environmental Physics, University of Bremen, Bremen, Germany \\ *now at: the School of Earth and Environment, University of Leeds, UK
}

Received: 10 April 2007 - Published in Atmos. Chem. Phys. Discuss.: 8 May 2007

Revised: 21 November 2008 - Accepted: 9 July 2009 - Published: 29 July 2009

\begin{abstract}
Balloon water vapour in situ and remote measurements in the tropical upper troposphere and lower stratosphere (UTLS) obtained during the HIBISCUS campaign around $20^{\circ} \mathrm{S}$ in Brazil in February-March 2004 using a tunable diode laser ( $\mu$ SDLA), a surface acoustic wave (SAW) and a Vis-NIR solar occultation spectrometer (SAOZ) on a long duration balloon, have been used for evaluating the performances of satellite borne remote water vapour instruments available at the same latitude and measurement period. In the stratosphere, HALOE displays the best precision (2.5\%), followed by SAGE II (7\%), MIPAS (10\%), SAOZ (20-25\%) and SCIAMACHY (35\%), all of which show approximately constant $\mathrm{H}_{2} \mathrm{O}$ mixing ratios between $20-25 \mathrm{~km}$. Compared to HALOE of $\pm 10 \%$ accuracy between $0.1-100 \mathrm{hPa}$, SAGE II and SAOZ show insignificant biases, MIPAS is wetter by $10 \%$ and SCIAMACHY dryer by $20 \%$. The currently available GOMOS profiles of $25 \%$ precision show a positive vertical gradient in error for identified reasons. Compared to these, the water vapour of the Reprobus Chemistry Transport Model, forced at pressures higher than $95 \mathrm{hPa}$ by the ECMWF analyses, is dryer by about $1 \mathrm{ppmv}(20 \%)$.

In the lower stratosphere between $16-20 \mathrm{~km}$, most notable features are the steep degradation of MIPAS precision below $18 \mathrm{~km}$, and the appearance of biases between instruments far larger than their quoted total uncertainty. HALOE and
\end{abstract}

SAGE II (after spectral adjustment for reducing the bias with HALOE at northern mid-latitudes) both show decreases of water vapour with a minimum at the tropopause not seen by other instruments or the model, possibly attributable to an increasing error in the HALOE altitude registration. Between $16-18 \mathrm{~km}$ where the water vapour concentration shows little horizontal variability, and where the $\mu$ SDLA balloon measurements are not perturbed by outgassing, the average mixing ratios reported by the remote sensing instruments are substantially lower than the $4-5$ ppmv observed by the $\mu$ SDLA. Differences between $\mu$ SDLA and HALOE and SAGE II (of the order of -2 ppmv), SCIAMACHY, MIPAS and GOMOS $(-1 \mathrm{ppmv})$ and SAOZ $(-0.5 \mathrm{ppmv})$, exceed the $10 \%$ uncertainty of $\mu$ SDLA, implying larger systematic errors than estimated for the various instruments.

In the upper troposphere, where the water vapour concentration is highly variable, AIRS v5 appears to be the most consistent within its $25 \%$ uncertainty with balloon in-situ measurements as well as ECMWF. Most of the remote measurements show less reliability in the upper troposphere, losing sensitivity possibly because of absorption line saturation in their spectral ranges (HALOE, SAGE II and SCIAMACHY), instrument noise exceeding 100\% (MIPAS) or imperfect refraction correction (GOMOS). An exception is the SAOZ-balloon, employing smaller $\mathrm{H}_{2} \mathrm{O}$ absorption bands in the troposphere.

\section{Correspondence to: N. Montoux} (nadege.montoux@latmos.ipsl.fr)

Published by Copernicus Publications on behalf of the European Geosciences Union. 


\section{Introduction}

Water vapour plays a key role in Upper Troposphere - Lower Stratosphere (UTLS) climate and chemistry. It strongly contributes to the stratospheric radiative balance via its greenhouse effect (e.g. Kiehl and Trenberth, 1997), and is the main precursor of $\mathrm{HO}_{x}$ radicals contributing to the catalytic destruction of ozone in the lower stratosphere (e.g. Wennberg et al., 1994; Osterman et al., 1997). In addition, the presence of cirrus clouds in the upper troposphere, highly dependent on the concentration of water vapour and the local temperature, also strongly impact the radiative balance (Jensen et al., 1994). As a result, a $20 \%$ increase of stratospheric water vapour such as that reported by Oltmans et al. $(1995,2000)$ could result in a substantial warming of the troposphere and cooling of the stratosphere (Forster and Shine, 1999). Recent observations indicate a levelling or a small decrease of stratospheric water vapour mixing ratios after 1996-2000 (Randel et al., 2006; Scherer et al., 2007; Dhomse et al., 2008; Rosenlof et al., 2008), attributed to a faster BrewerDobson circulation, but the question of the mechanism controlling the amount of water vapour in the stratosphere still remains. Indeed the observed increase in $\mathrm{CH}_{4}$ mixing ratios is insufficient to explain the magnitude of the increase before 2000. While some of the water vapour inter-annual variability appears linked to changes in zonal mean temperatures (Fueglistaler and Haynes, 2005; Fueglistaler et al., 2005), the observed overall cooling of the tropical tropopause is apparently in contradiction with the longer-term water vapour trends (Kley et al., 2000). Thus, although debated for 20 years (Sherwood and Dessler, 2000 and references herein), the processes controlling hydration or dehydration of the tropical lower stratosphere are still not fully resolved. One reason for this is the lack of reliable water vapour observations in the tropical UTLS, limited to a few balloon and high altitude aircraft measurements, and the difficulty of remote measurements from space at altitudes where cirrus clouds are frequently present.

The objective of this paper is to exploit the in-situ and remote balloon water vapour measurements in the UTLS obtained during the HIBISCUS campaign in Brazil in February-March 2004 (Pommereau et al., 2007) to evaluate the precision and accuracy of HALOE, SAGE II, MIPAS, GOMOS, SCIAMACHY and AIRS observations available at the same latitude during the period of the balloon flights. The launch of the AURA-Microwave Limb Sounder was delayed to after the end of the HIBISCUS measurement period.

One critical constraint when comparing balloon and satellite measurements of the highly variable water vapour in the troposphere is the limited number of true collocated observations of the two types of platforms. To address this difficulty, the approach adopted here is to use as a reference the $2^{\circ} \times 2^{\circ}$ resolution water vapour profiles available every $6 \mathrm{~h}$ from a combination of the ECMWF (European Centre for Medium-range Weather Forecasts) analyses which extend to
$95 \mathrm{hPa}$, further extended upward by the Reprobus ChemistryTransport Model (CTM). These model profiles, in which routine water vapour radiosoundings up to $300 \mathrm{hPa}$ are assimilated, provide an indication of possible changes of atmospheric water vapour between the locations of the measurements. Using this technique, three types of comparisons have been made: i) balloon in-situ with the closest available satellite measurements; ii) statistical comparisons of collocated long duration balloon and satellite measurements to modelled profiles; and iii) zonal mean comparisons of the same between $10^{\circ}-20^{\circ} \mathrm{S}$ and $20^{\circ}-30^{\circ} \mathrm{S}$.

Section 2 provides brief descriptions of each instrument and their known performances, as well as of the ReprobusECMWF model. The comparisons by the three techniques are then shown in Sect. 3, and the relative performances of all systems summarised in Sect. 4.

\section{Measured and modelled water vapour profiles}

The balloon measurements available from HIBISCUS are those of two in-situ instruments: a tuneable diode laser spectrometer ( $\mu$ SDLA) and a Surface Acoustic Wave (SAW) hygrometer flown on short duration balloons from Bauru $\left(22^{\circ} \mathrm{S}, 49^{\circ} \mathrm{W}\right)$ in Brazil; and the remote solar occultation measurements of a visible near IR SAOZ spectrometer flown on an Infra-Red Montgolfier balloon launched from the same location which executed a 39-day circumnavigation flight. For the satellite instruments, the data available during the same period at the southern tropics are those of SAGE II, HALOE, GOMOS, MIPAS, SCIAMACHY and AIRS. A summary of the technical characteristics of each is provided in Table 1.

\section{1 $\mu$ SDLA tunable diode laser spectrometer}

The $\mu$ SDLA (Micro Spectromètre à Diodes Laser Accordables) is a near-infrared tunable diode laser spectrometer (Durry and Megie, 1999), which measures in-situ $\mathrm{H}_{2} \mathrm{O}, \mathrm{CO}_{2}$ and $\mathrm{CH}_{4}$ concentrations. Three InGaAs diode laser beams are directed into a $28 \mathrm{~m}$ absorption path using an open optical multi-pass cell. Gas concentrations are retrieved from the in-situ absorption spectra using the Beer-Lambert law and a molecular model. $\mathrm{H}_{2} \mathrm{O}$ atmospheric spectra are recorded in the $1.39 \mu \mathrm{m}$ spectral region (Durry et al., 2005). The technique provides concentrations at high temporal resolution ranging from one to four samples per second, achieving a spatial resolution of the order of ten meters. The dynamical range of the measurements is four orders of magnitude, allowing observations in both the lower stratosphere and the upper troposphere. The accuracy is estimated to be in the range $5-10 \%$, the figure being confirmed by direct comparison with a frost point hygrometer (Durry et al., 2005). During the HIBISCUS campaign, the $\mu$ SDLA instrument was flown twice on board short duration stratospheric balloons, 
Table 1. Summary of characteristics of balloon and satellite water vapour measurements.

\begin{tabular}{|c|c|c|c|c|c|}
\hline Platform & Instrument & Technique & Spectral Region & Vertical/Spatial resolution & Estimated Accuracy \\
\hline \multirow[t]{3}{*}{ Balloon } & $\mu \mathrm{SDLA}$ & $\begin{array}{l}\text { In-situ tunable diode } \\
\text { laser }\end{array}$ & $1.39 \mu \mathrm{m}$ & $10 \mathrm{~m} / \mathrm{NA}$ & $5-10 \%$ \\
\hline & SAW & $\begin{array}{l}\text { In-situ Surface Acoustic } \\
\text { Wave }\end{array}$ & not applicable & variable & variable \\
\hline & SAOZ & $\begin{array}{l}\text { Near IR spectro } \\
\text { Solar Occultation }\end{array}$ & $\begin{array}{l}700-845 \mathrm{~nm} \\
15 \mathrm{~km}) \\
920-960 \mathrm{~nm} \\
(>15 \mathrm{~km})\end{array}$ & $1.4 \mathrm{~km} / 200 \mathrm{~km}$ & $\begin{array}{l}\text { Random } 5 \% \text { at } 17 \mathrm{~km} \text {, } \\
10 \% \text { at } 23 \mathrm{~km} \\
\text { Accuracy: } 20 \%\end{array}$ \\
\hline \multirow[t]{6}{*}{ Satellite } & $\begin{array}{l}\text { SAGE II } \\
\text { V } 6.2\end{array}$ & $\begin{array}{l}\text { Vis photometer } \\
\text { Solar Occultation }\end{array}$ & $945 \mathrm{~nm}$ & $1 \mathrm{~km} / 200 \mathrm{~km}$ & $\begin{array}{l}\text { Total } \\
10-20 \%(10-40 \mathrm{~km})\end{array}$ \\
\hline & HALOE V19 & $\begin{array}{l}\text { broadband IR phot. } \\
\text { Solar Occultation }\end{array}$ & $6.61 \mu \mathrm{m}$ & $2.3 \mathrm{~km} / 200-400 \mathrm{~km}$ & $\begin{array}{l}\text { Random 5\% } \\
\text { Accuracy 10\% } \\
(0.1-100 \mathrm{hPa})\end{array}$ \\
\hline & $\begin{array}{l}\text { MIPAS } \\
\text { V4.62 }\end{array}$ & $\begin{array}{l}\text { FTS Limb } \\
\text { Thermal emission }\end{array}$ & $\begin{array}{l}6.1 \mu \mathrm{m} \\
10.5 \mu \mathrm{m} \\
12.4 \mu \mathrm{m}\end{array}$ & $3-4 \mathrm{~km} / 300-500 \mathrm{~km}$ & $\begin{array}{l}\text { Random 6-25\% } \\
\text { Accuracy. } 13-40 \%\end{array}$ \\
\hline & $\begin{array}{l}\text { GOMOS } \\
\text { V6.0c_6.0f }\end{array}$ & $\begin{array}{l}\text { Near IR Spectro } \\
\text { Star Occultation }\end{array}$ & $926-956 \mathrm{~nm}$ & $2-4 \mathrm{~km} / 300 \mathrm{~km}$ & $\begin{array}{l}\text { Total } 10-25 \% \\
(16-25 \mathrm{~km})\end{array}$ \\
\hline & $\begin{array}{l}\text { SCIAMACHY } \\
\text { V1.0 (preliminary) }\end{array}$ & $\begin{array}{l}\text { Near IR } \\
\text { Limb scattering }\end{array}$ & $1375-1390 \mathrm{~nm}$ & $3.3-4.5 \mathrm{~km} / 240 \mathrm{~km} \times 400 \mathrm{~km}$ & $\begin{array}{l}\text { Precision } \\
20-30 \%(14-21 \mathrm{~km}) \\
30-40 \%(10-12 \mathrm{~km}) \\
30-40 \%(21-23 \mathrm{~km}) \\
\text { Accuracy } \\
20 \%(14-21 \mathrm{~km})\end{array}$ \\
\hline & $\begin{array}{l}\text { AIRSv4/v5/ } \\
\text { AMSU }\end{array}$ & $\begin{array}{l}\mathrm{IR} / \text { microwave } \\
\text { nadir }\end{array}$ & $\begin{array}{l}6.23-7.63 \mu \mathrm{m} \\
3.63-3.83 \mu \mathrm{m}\end{array}$ & $2 \mathrm{~km} / 50 \mathrm{~km}$ & $\begin{array}{l}\text { Total } \\
25 \% \mathrm{P}>150 \mathrm{hPa}(\mathrm{v} 3 / \mathrm{v} 4)\end{array}$ \\
\hline
\end{tabular}

on the 13 and 24 February 2004 (Durry et al., 2006; Pommereau et al., 2007). To avoid contamination of the measurements by outgassing from the gondola or the balloon envelope, only data recorded during the slow $(1.5 \mathrm{~m} / \mathrm{s})$ nighttime descent of the balloon is considered.

\subsection{SAW hygrometer}

The University of Cambridge (UCAM) Surface Acoustic Wave (SAW) instrument (Hansford et al., 2006) is an in situ dew-/frost-point hygrometer based on a $250-\mathrm{MHz}$ surfaceacoustic-wave sensor. The physical principle is as follows. A quartz chip is cooled by a thermoelectric cooler until water vapour condenses into water or ice on it. Mass loading by water or ice on the chip is detected by its effect on the velocity and amplitude of the acoustic waves. A feedback control loop maintains a constant amount of condensate on the quartz chip surface and so equilibrium between the condensed phase and the vapour phase just above the surface is established. The water vapour pressure in the air is then equal to the saturated water vapour pressure at the temperature of the surface using the Clausius Clapeyron relation. Alternatively, the temperature of the SAW chip may be cycled above and below the dew- or frost-point temperature and the water vapour pressure deduced from the chip temperature at the onset of condensation, but this method has the disadvantage of a much lower vertical resolution for balloon flights. Finally, the water vapour concentration is calculated from the measured surface temperature using the Wagner et al. (1994) formulation for ice (i.e., for temperatures below $273.16 \mathrm{~K}$ ). The accuracy of the temperature measurement is estimated to be equivalent to $\pm 0.3^{\circ} \mathrm{C}$ (Hansford et al., 2006). However, the water vapour accuracy and precision are difficult to estimate because they depend, among others, on the dew-/frost-point recorded and on the speed of the balloon. Here, each SAW data file gives the estimated errors in the vapour concentration, taking into account both the accuracy and the precision. During the HIBISCUS campaign, the instrument was flown on board the same balloons as the $\mu$ SDLA instrument. 


\subsection{SAOZ spectrometer}

The instrument used here is a visible near IR $(400-1000 \mathrm{~nm})$ extended version of the SAOZ (Système d'Analyse par Observation Zénithale) diode array UV-visible spectrometer (Pommereau and Piquard, 1994) designed for the measurement of $\mathrm{O}_{3}, \mathrm{NO}_{2}$ and other species by solar occultation at sunrise and sunset. Water vapour is measured in three wavelength ranges: between $585-670 \mathrm{~nm}$ below $12 \mathrm{~km}$ in the troposphere, between $700-845 \mathrm{~nm}$ between $12-15 \mathrm{~km}$, and $920-960 \mathrm{~nm}$ above in the stratosphere, with a spectral resolution of $1.2 \mathrm{~nm}$. The spectra are analyzed by simulating the transmission along the light path calculated by ray tracing using the water vapour absorption lines of the HITRAN database (Rothman et al., 2005). Trace gas profiles $\left(\mathrm{O}_{3}, \mathrm{NO}_{2}, \mathrm{O}_{4}\right.$ and $\left.\mathrm{H}_{2} \mathrm{O}\right)$ are retrieved by the so-called onionpeeling technique within one-kilometre thick layers. The retrieval assumes constant water vapour mixing ratios above the balloon. The vertical resolution is $1.4 \mathrm{~km}$ corresponding to the half-width of the solar disk brightness. The vertical sampling is about $1 \mathrm{~km}$ and the horizontal resolution $200 \mathrm{~km}$. The altitude registration, verified using collocated measurements during an overpass of the balloon over an ozone lidar is better than $\pm 100 \mathrm{~m}$ (Borchi et al., 2005). Data contaminated by clouds are detected using the atmospheric extinction at $615 \mathrm{~nm}$ and removed. The estimated precision of water vapour measurements is $5 \%$ at $17 \mathrm{~km}$, degrading progressively at higher altitude $(10 \%$ at $23 \mathrm{~km})$. The accuracy of the current retrieval is approximately $20 \%$. During HIBISCUS, the SAOZ instrument was flown on an Infra-Red Montgolfier (MIR) balloon for a 39-day flight (26 February4 April 2004) providing one and a half circumnavigations of the globe between $10-20^{\circ} \mathrm{S}$ and 68 water vapour profiles, divided equally between sunrise and sunset (Borchi and Pommereau, 2007). However, because of the diurnal cycle of the balloon altitude, the measurements are limited to altitudes below $24-25 \mathrm{~km}$ at sunset and $18-22 \mathrm{~km}$ at sunrise depending on the cloud cover. In addition, as for all solar occultation systems, observations in the troposphere are limited to cloud free areas. Water vapour number densities are converted into mixing ratios using ECMWF pressure and temperature at the tangent point of the balloon measurements.

\subsection{SAGE II}

SAGE II (Stratospheric Aerosol and Gas Experiment II) is a sun-pointing photometer which measures the attenuated solar radiation through the Earth's limb in seven channels centred at wavelengths ranging from 0.385 to $1.02 \mu \mathrm{m}$. SAGE II was launched on 5 October 1984 on board the ERBS (Earth Radiation Budget Satellite) satellite (Mauldin et al., 1985) and provided measurements up to 22 August 2005. The water vapour measurements initially derived from the spectral channel centred on $935 \mathrm{~nm}$ are now, with the version 6.2 of the retrieval used in this study, derived from a spectral channel centred on $945 \mathrm{~nm}$ with a full-width half maximum of $33 \mathrm{~nm}$ (Thomason et al., 2004). These spectral shift and width have been selected to reduce the differences in the 15-34 km altitude range between the SAGE II V6.1 and HALOE V19 mean 1996-1999 northern mid-latitudes profiles. The V6.2 version corrects the dry bias observed in older versions in the lower stratosphere and in the vicinity of the hygropause, i.e., the altitude of water vapour minimum (Taha et al., 2004; Chiou et al., 2004). The vertical resolution is approximately $1 \mathrm{~km}$ and the sampling $0.5 \mathrm{~km}$. The spatial resolution is $200 \mathrm{~km}$ along the line of sight and $2.5 \mathrm{~km}$ perpendicular to the line of sight. The uncertainty given for version 6.2 products is the total uncertainty whose largest source is associated to the imperfect removal of the aerosol contribution (Thomason et al., 2004). Comparisons with ATLAS/ATMOS (Chiou et al., 2004), indicate that water vapour mixing ratio uncertainties are most probably overestimated by at least a factor of 2 to 3 especially in the lower stratosphere. Those comparisons along with those made by Taha et al. (2004) reveal agreement within 10-20\% over an ltitude range of $15-40 \mathrm{~km}$ between SAGE II and other instruments. SAGE II data used in this study are those available at http://www-sage2.larc.nasa.gov/Version6-2Data.html.

\subsection{HALOE}

HALOE (HALogen Occultation Experiment) is a solar occultation infrared limb sounder launched on 12 September 1991 on board the UARS (Upper Atmosphere Research Satellite) spacecraft (Russell et al., 1993), which provided measurements up to 21 November 2005 . The broadband radiometry technique allows the retrieval of water vapour between 10 and $85 \mathrm{~km}$ from a channel centred on $6.61 \mu \mathrm{m}$. The data used in this study are the version 19 retrieval products. They have been screened for cirrus cloud contamination as described by Hervig and McHugh (1999). The vertical resolution is about $2.3 \mathrm{~km}$ and the sampling $0.3 \mathrm{~km}$. The horizontal resolution is $200-400 \mathrm{~km}$ along the line-of-sight and $10 \mathrm{~km}$ perpendicular to the line-of-sight. Intercomparisons with several others instruments (Harries et al., 1996; Kley et al., 2000) indicate that the HALOE water vapour measurements are expected to be accurate to within $\pm 10 \%$ or better in the height range $0.1-100 \mathrm{hPa}$ with a precision of $5 \%$ or less in much of the stratosphere. The HALOE data are those made available at: http://daac.gsfc.nasa.gov/data/datapool/UARS/ HALOE/L2/.

\subsection{MIPAS}

The Michelson Interferometer for Passive Atmospheric Sounding (MIPAS) is a limb-viewing mid-Infrared highresolution Fourier transform spectrometer (Fischer et al., 2000 and 2008). This instrument is operated on ENVISAT (ENVIronmental SATellite) launched on 1 March 2002 (ESA, 1998). ENVISAT has a sun-synchronous polar 
orbit of $98.55^{\circ}$ inclination, $100.5 \mathrm{~min}$ period and $785 \mathrm{~km}$ altitude. The atmospheric limb emission spectrum is measured in five spectral bands from 4.15 to $14.6 \mu \mathrm{m}$ with a spectral resolution of $0.025 \mathrm{~cm}^{-1}$ (unapodized). Four microwindows are used for the water vapour retrieval: around $6.1 \mu \mathrm{m}$ for altitudes above $15 \mathrm{~km}$ and around 10.5 and $12.4 \mu \mathrm{m}$ for altitudes between 6 and $18 \mathrm{~km}$ (Raspollini et al., 2006). Seventeen spectra at tangent altitudes from 6 to $68 \mathrm{~km}$ allow the retrieval of water vapour profiles with a vertical sampling of $3 \mathrm{~km}$ in the upper troposphere and in the stratosphere. The horizontal resolution is about $300 \mathrm{~km}$ along the line of sight and $30 \mathrm{~km}$ perpendicular to the line of sight (Fischer et al., 2008). The MIPAS data used in this study are those of the version 6.2 retrieval algorithm, available at http://envisat.esa. int/object/index.cfm?fobjectid=1381\&id=11. The retrieval algorithm contains a cloud filtering scheme which removes data at tangent altitudes where clouds are detected, resulting typically in the rejection of $60 \%$ of the measurements at $12 \mathrm{~km}$ in the Tropics (Fischer et al., 2008). A comprehensive study of systematic and random errors of the MIPAS data has been made available by Raspollini et al. (2006) and results for five different atmospheric conditions are available at http:/www.atm.ox.ac.uk/group/mipas/err. For equatorial locations, at altitudes between $12-24 \mathrm{~km}$ random and systematic errors fluctuate between 6.4 and $25.0 \%$ and between 13.3 and $40.5 \%$ respectively, with a maximum error around $15 \mathrm{~km}$. The total error varies then between 14.8 and $47.6 \%$ at these altitudes. However, Piccolo and Dudhia (2007) showed that the standard deviation between pairs of MIPAS profiles in coincidence, normally representative of the precision of the data is one or two times greater than the calculated random error ( $\sim 1 \mathrm{ppmv}$ between 12 and $21 \mathrm{~km}$ in the tropics and subtropics) which could be due to horizontal inhomogeneity of the atmosphere as well as instabilities in the retrieval. However, the MIPAS water vapour profiles show essentially no bias in the altitude region between 10 and $100 \mathrm{hPa}$ with respect to various validation data (Fischer et al., 2008). On the other hand, there seems to be a low bias in the tropopause region and some oscillations in the vertical profiles in the upper troposphere (Fischer et al., 2008; Piccolo and Dudhia, 2007; Oelhaf et al., 2004). Because of a known error in the tangent height (Kiefer et al., 2007), the altitude used in this study is that derived from MIPAS retrieved pressure, with an uncertainty of about $70 \mathrm{~m}$ (Raspollini et al., 2006).

\subsection{GOMOS}

The Global Ozone Monitoring by Occultation of Stars (GOMOS) instrument is a UV-visible-near-infrared spectrophotometer (Bertaux et al., 2001), also on ENVISAT. GOMOS uses stellar occultation in four distinct spectral bands, the spectral band dedicated to the water vapour retrieval (i.e., the IR2 band) extending from 916 to $956 \mathrm{~nm}$. In order to reduce the random noise due to atmospheric scintillation, vertical profiles are smoothed using a Tikhonov regularisation with a target resolution depending on species (Kyrölä et al., 2006). For $\mathrm{H}_{2} \mathrm{O}$, the resulting final vertical resolution of $2 \mathrm{~km}$ below $20 \mathrm{~km}$, increases linearly to $4 \mathrm{~km}$ at $30 \mathrm{~km}$ and remains constant above. The horizontal resolution is about $300 \mathrm{~km}$ and the vertical sampling $400-500 \mathrm{~m}$. The precision of the measurement depends on the star temperature $(T)$ and brightness (defined by its visual magnitude mv) with higher accuracy for night-time measurements on cold and low visual magnitude (bright) stars. The expected precision is better around $16-24 \mathrm{~km}$ ranging from $10 \%(T=3000 \mathrm{~K}, \mathrm{mv}=1)$ to $25 \%$ $(T=11000 \mathrm{~K}$ and $\mathrm{mv}=1)$ or greater for hotter and dimmer stars (http://envisat.esa.int/instruments/gomos/). The precision is expected to degrade below and above the $16-24 \mathrm{~km}$ altitude range. GOMOS $\mathrm{H}_{2} \mathrm{O}$ profiles have not been validated to date and this study presents the first attempt to evaluate their accuracy by comparison with independent measurements. The data used in this study are night-time $\mathrm{H}_{2} \mathrm{O}$ "local density" profiles issued only from occultations of the Antares and Toliman stars, produced by the V6.0c_6.0f research retrieval algorithm.

\subsection{SCIAMACHY}

The SCanning Imaging Absorption spectroMeter for Atmospheric CHartographY (SCIAMACHY) (Burrows et al., 1995; Bovensmann et al., 1999) is also onboard ENVISAT. The instrument is a passive imaging spectrometer comprising 8 spectral channels covering a wide spectral range from 240 to $2400 \mathrm{~nm}$. Each spectral channel comprises a grating spectrometer having a 1024 element diode array as a detector. For the current study only measurements in the spectral channel 6 are used, which measures from 1050 to $\sim 1700 \mathrm{~nm}$. The spectral resolution FWHM is $\sim 1.5 \mathrm{~nm}$ for the spectral sampling of $\sim 0.76 \mathrm{~nm}$. In the limb viewing geometry the SCIAMACHY instrument observes the atmosphere tangentially to the Earth's surface starting at about $3 \mathrm{~km}$ below the horizon, i.e., when the Earth's surface is still within the field of view of the instrument, and then scanning vertically up to the top of the atmosphere (about $100 \mathrm{~km}$ tangent height). At each tangent height a horizontal scan of the duration of $1.5 \mathrm{~s}$ is performed followed by an elevation step of about $3.3 \mathrm{~km}$. No measurements are performed during the vertical repositioning. Thus, the limb observation sequence is carried out with a vertical sampling of $3.3 \mathrm{~km}$. The vertical instantaneous field of view is about $2.6 \mathrm{~km}$ at the tangent point. Although the horizontal instantaneous field of view is about $110 \mathrm{~km}$ at the tangent point, the horizontal resolution is mainly determined by the integration time during the horizontal scan reaching typically about $240 \mathrm{~km}$. For this study, SCIAMACHY Level 1 data of version 6.03 were used with all calibration steps applied.

The vertical distributions of water vapour used in this study were retrieved from measurements of scattered solar radiation in the limb viewing geometry. These are derived as a pre-operational product. The retrieval is achieved by 
the differential two-step inversion approach implemented in the SCIATRAN software package (Rozanov et al., 2005a; Rozanov, 2008) exploiting the differential absorption structure of the water vapour in the $1375-1390 \mathrm{~nm}$ spectral range. Analyzing the information content of the limb observations, only measurements performed at tangent heights between 12 and $30 \mathrm{~km}$ were found to contribute information significantly and, thus, only the limb spectra obtained at these tangent heights are used by the retrieval algorithm. In general, the retrieval algorithm is similar to those employed at IUP Bremen to retrieve the vertical distributions of other minor atmospheric species, e.g., $\mathrm{O}_{3}, \mathrm{NO}_{2}$, and $\mathrm{BrO}$ (Rozanov et al., 2005b, 2007; Von Savigny et al., 2005). All spectral fits are performed for the differential absorption structure which is obtained subtracting the linear polynomials from the limb spectra at all tangent heights of interest. This avoids the need to account for broadband spectral features due to unknown atmospheric parameters such as surface albedo and aerosols. At the first retrieval step, a spectral fit is performed for each tangent height independently to account for a possible wavelength misalignment. Thereafter, the corrected spectra are passed to the main inversion algorithm, which employs the global fit approach. The measurement vector comprises all spectral points in the selected spectral range obtained at all tangent heights of interest and the optimal estimation type (Rodgers, 2000) inversion is used to gain the vertical distributions of the water vapour. The main differences of the inversion method employed here to the standard optimal estimation technique are that the statistical constraint is strongly relaxed (the a priori standard deviation is set to $4000 \%$ ) and an additional smoothing constraint is used instead. The noise covariance is determined by the fit residuals obtained at the preprocessing step. The non-linearity of the problem is accounted for using the Newton type iterative approach. The simulated spectra and appropriate weighting functions are calculated with the SCIATRAN radiative transfer model, which includes a fully spherical treatment of the singly scattered radiation and an approximation to account for the multiple scattering contribution (Rozanov at al., 2001). The weighting functions are calculated in the single scattering approximation.

The spectral absorption features of the water vapour are accounted for employing the correlated-k distribution scheme (Buchwitz et al., 2000) with ESFT coefficients calculated using the HITRAN 2004 database (Rothman et al., 2005). The forward model is initialized using the global pressure and temperature as well as surface elevation information provided by ECMWF and a water vapour vertical distribution according to the US Standard 1976 (NASA, 1976) model atmosphere. Furthermore, a background aerosol loading according to the LOWTRAN parameterization (Kneizys et al., 1986) and a constant surface albedo of 0.3 are assumed. Only the measurements with clouds below $10 \mathrm{~km}$ (or at cloud free conditions) were considered in this study. The effect of the lower clouds is not considered during the retrieval.
After first analyses of the results from this new algorithm (Rozanov et al., in preparation, 2009), the retrievals, described above, have been shown to yield good information between 12 and $23 \mathrm{~km}$, a retrieval precision of $20-35 \%$ was achieved per measurement. First comparison results show good agreement with other instruments between 14 and $21 \mathrm{~km}$ i.e. within about $20 \%$. Above $21 \mathrm{~km}$ and below $14 \mathrm{~km}$ the retrieval shows more variability with a standard deviation of 30-40\%. The results presented here are the first retrievals of water vapour vertical distributions performed using this new algorithm. The internal version number of the retrieval algorithm presented here is 1.0. Potential for further improvement is being considered. The current algorithm is however optimized for the retrieval of $\mathrm{H}_{2} \mathrm{O}$ in the lower stratosphere. The dataset used in this study was processed manually. The procedure for a routinely running processor to retrieve the vertical distributions of the water vapour on the global scale is in development.

\subsection{AIRS/AMSU}

AIRS (Atmospheric Infrared Sounder) is a cross-track nadir scanning sounder launched on 4 May 2002 on board the EOS (Earth Observing System) AQUA satellite. AQUA has a near-polar and sun-synchronous orbit of $98.2^{\circ}$ inclination and $98.8 \mathrm{~min}$ period, at an altitude of $705 \mathrm{~km}$ (Parkinson, 2003). The infrared spectrum is measured in 2378 channels covering the spectral range 3.7-15.4 $\mu \mathrm{m}$ with a spectral resolution $\lambda \Delta \lambda \sim 1200$ and 4 visible and near infrared channels covering the $0.4-0.94 \mu \mathrm{m}$ spectral range. Of those channels, 41 are used for water vapour retrieval (33 in the range $6.23-7.63 \mu \mathrm{m}$ and 8 in the range $3.63-3.83 \mu \mathrm{m}$ ). Nadir scanning allows sounding most of the globe twice daily with a horizontal resolution of $13.5 \mathrm{~km}$ (geo-location accuracy of $1.7 \mathrm{~km}$ ) in the infrared and of $2.3 \mathrm{~km}$ in the visible and nearinfrared. In the vertical, the AIRS level 2 processing provides measurements within $1 \mathrm{~km}$ layers in the troposphere and 3$5 \mathrm{~km}$ in the stratosphere. AMSU-A (Advanced Microwave Sounding Unit A), also aboard the AQUA spacecraft, is a microwave temperature/humidity radiometer formed with two independent modules: AMSU-A1 (12 channels between 50$58 \mathrm{GHz}$ and 1 channel at $89 \mathrm{GHz}$ ) and AMSU-A2 (2 channels at $23.8 \mathrm{GHz}$ and $31.4 \mathrm{GHz}$ ) (Rosenkranz et al., 2001). Because microwave radiation, unlike infrared radiation, is not sensitive to clouds, nine AIRS $13.5 \mathrm{~km}$ footprint infrared data are combined with one $40 \mathrm{~km}$ AMSU footprint in the microwave, to provide a single "cloud-clear" infrared spectrum (Aumann et al., 2003 and Susskind et al., 2003 for more details). The water vapour profiles are then obtained over footprints of $45 \mathrm{~km} \times 45 \mathrm{~km}$ with a horizontal resolution of $50 \mathrm{~km}$. Compared to in-situ balloon and aircraft measurements, the AIRS version 3 data showed agreement within $25 \%$ in the tropics between 500 and $100 \mathrm{hPa}$ and even better for more spatially $(<50-100 \mathrm{~km})$ and temporally restricted criteria ( $<1 \mathrm{~h}$ ) (Hagan et al., 2004). Further comparisons 
Table 2. SF-2. Instruments and location of water vapour measurements on 13 and 14 February 2004.

\begin{tabular}{lrrrcrc}
\hline Instrument & Date and Time UTC & Latitude & Longitude & $\begin{array}{c}\text { Distance to } \\
\mu \text { SDLA }(\mathrm{km})\end{array}$ & $\begin{array}{c}\text { Time difference } \\
(\mathrm{min}) \text { with Reprobus }\end{array}$ & $\begin{array}{c}\text { Distance from } \\
\text { Reprobus }(\mathrm{km})\end{array}$ \\
\hline$\mu$ SDLA & 13 Feb. 23:00 & $22.09^{\circ} \mathrm{S}$ & $49.24^{\circ} \mathrm{W}$ & 0 & 0.5 & $\sim 76$ \\
HALOE & 13 Feb. 09:19 & $25.22^{\circ} \mathrm{S}$ & $52.59^{\circ} \mathrm{W}$ & $\sim 475$ & 3.7 & $\sim 98$ \\
SCIAMACHY & 14 Feb. 13:09 & $26.47^{\circ} \mathrm{S}$ & $56.50^{\circ} \mathrm{W}$ & $\sim 883$ & 5.9 & $\sim 96$ \\
AIRS & 13 Feb. 16:52 & $22.35^{\circ} \mathrm{S}$ & $48.93^{\circ} \mathrm{W}$ & $\sim 41$ & 7.3 & $\sim 95$ \\
\hline
\end{tabular}

between AIRS version 3 and aircraft measurements by Gettelman et al. (2004) confirmed the agreement within $25 \%$ at pressures higher than $150 \mathrm{hPa}$ and water vapour mixing ratios greater than $10 \mathrm{ppmv}$, below which the AIRS data are not representative of the real atmosphere as they are strongly weighted by the a priori profile used in the retrieval. The AIRS version 4 and MLS-AURA version 2.2 water vapour profiles were also shown to be broadly consistent at pressures higher than $200 \mathrm{hPa}$, when excluding mixing ratios lower than 20 ppmv (Read et al., 2007). Between 316 and $178 \mathrm{hPa}$, AIRS agrees with MLS to within $10 \%$ and is generally slightly wet biased compared to MLS. In contrast, comparisons with water vapour sondes at pressures lower than $300 \mathrm{hPa}$ reveal a $10 \%$ dry bias in the AIRS version 4 water vapour data. However this bias is comparable to the absolute accuracy of the sondes (Tobin et al., 2006 and Divakarla et al., 2006). The data used in this study are from the version-5 retrieval (see http://disc.sci.gsfc.nasa.gov/data/ datapool/AIRS/index.html), and consist of mean layer mixing ratios in the first 14 of the 28 pressure layers used in version-4, i.e. from the surface to $50 \mathrm{hPa}$.

\subsection{Reprobus-ECMWF model}

Reprobus is a three-dimensional Chemistry-Transport Model (CTM) constrained by ECMWF analyses (Lefèvre et al., 1994). The model calculates the densities of 55 chemical species using 150 photolytic gas-phase and heterogeneous reactions. 40 individual constituents or chemical families are explicitly transported by a semi-lagrangian scheme with a time step of $15 \mathrm{~min}$. The model extends from the surface up to $0.1 \mathrm{hPa}$ on 42 hybrid pressure levels. The horizontal resolution is $2^{\circ}$ in latitude and longitude. Wind, temperature and pressure are provided by the T511L60 6hourly ECMWF operational analyses and are interpolated to the model resolution as input. In the troposphere from the surface up to $95 \mathrm{hPa}$, the water vapour mixing ratios are taken directly from the ECMWF analyses. In the stratosphere, where water vapour observations are not assimilated by ECMWF, Reprobus computes explicitly the threedimensional transport of $\mathrm{H}_{2} \mathrm{O}$ and its production by methane oxidation. The fact that winds from meteorological analysis produce an excessively strong Brewer-Dobson circulation in the stratosphere is a well-documented problem (see for example Monge-Sanz et al., 2007, and references therein) which affects the ability of CTMs to represent the distribution of long-lived tracers. For water vapour, the overrapid vertical ascent does not allow sufficient hydration by methane oxidation of the air that propagates from the tropical tropopause to the upper stratosphere, causing Reprobus to be in general dry biased in the stratosphere. In the stratosphere, the model profiles presented here are used as an independent reference for the various experimental data, although it may underestimate the atmospheric variability and thus should be considered as lower limit for variability. Below the tropopause, the water vapour data assimilated into the ECMWF analysis are humidity profiles from radiosondes and radiances measured from a number of geostationary and polar orbiting satellites, including those of AIRS (Andersson et al., 2007). Although infrared radiances are given a reduced weight in ECMWF analyses, this must be kept in mind when comparing AIRS to the model water vapour profiles. Recent comparisons with in situ measurements made by the MOZAIC commercial aircraft between 10-12 km (Luo et al., 2008) show that ECMWF could be dry biased by $10-30 \%$, partly due to the absence of supersaturation in the model but also likely because of the $20 \%$ underestimation of water vapour in the upper troposphere by the Vaiisala RS- 80 probes assimilated in the model (Nuret et. al., 2008).

\section{Water vapour profile comparisons}

\subsection{Collocated balloon in-situ and satellites remote pro- files}

The balloons carrying the in-situ $\mu$ SDLA and a UCAMSAW were flown from Bauru within the convectively active South Atlantic Convergence Zone, on 13 (SF-2) and 24 (SF4) February 2004. The flights and the meteorological conditions within which they were performed are described by Durry et al. (2006) and Pommereau et al. (2007). The $\mathrm{H}_{2} \mathrm{O}$ profiles obtained on these flights have been compared to the closest available satellite observations and the closest model profile. Their location and the distance between them are given in Table 2 for flight SF-2, and Table 3 for flight SF-4. The first balloon (SF-2) was launched on 13 February 2004 


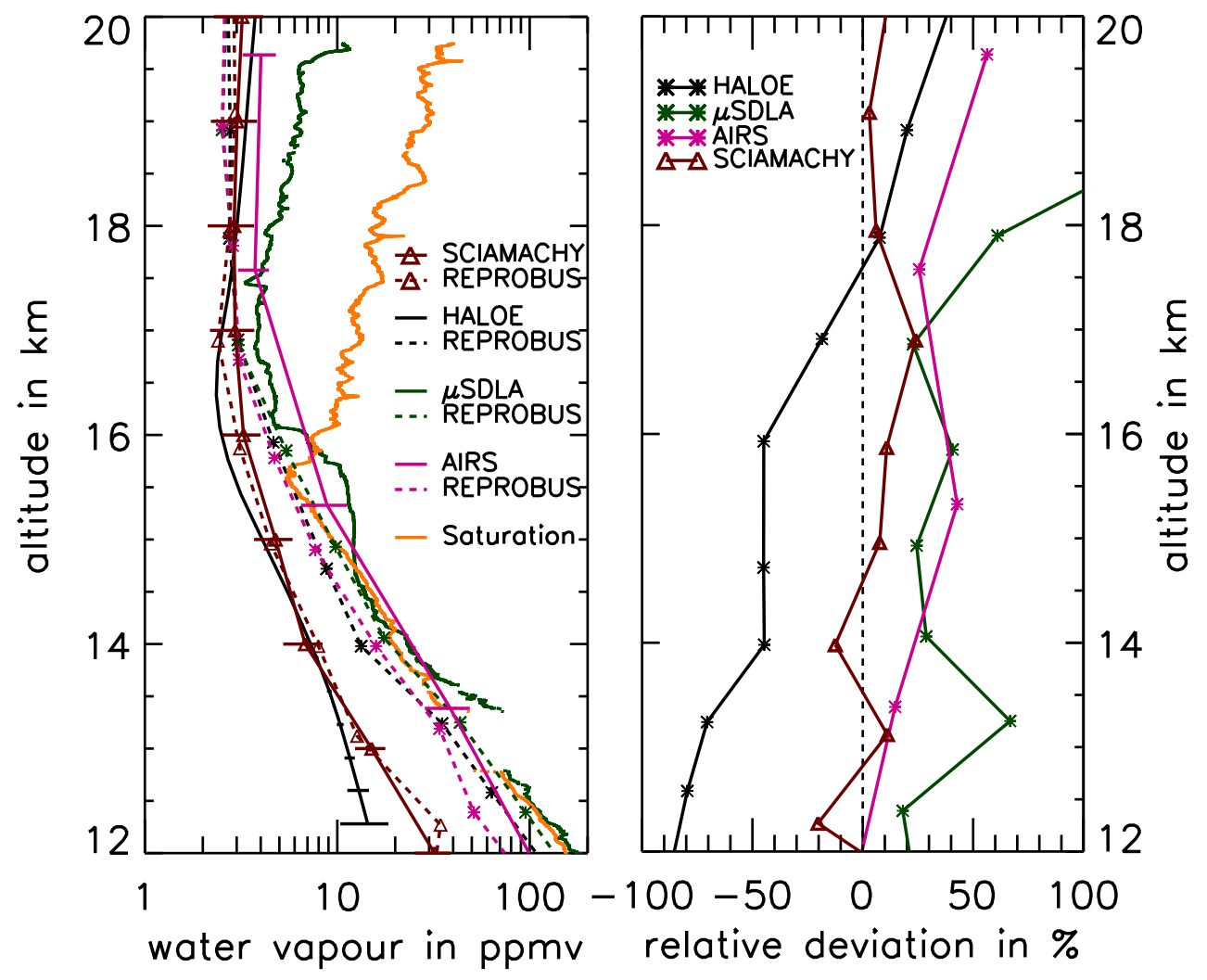

Fig. 1. SF2 flight on 13 February. Left: water vapour profiles, $\mu$ SDLA (green), HALOE (black), SCIAMACHY (brown) and AIRS (pink) including error bars available in the data files, compared to their closest respective Reprobus-ECMWF profile (same colour, dashed), and saturation ratio over ice at the balloon location (solid orange). Right: percent relative deviation of the different measurements from the model.

at 20:18 UTC (17:18 LT) some $300 \mathrm{~km}$ East of a strong convective system over the western part of the state of Sao Paulo (Pommereau et al., 2007). Among the instruments, it was carrying a SAW hygrometer and $\mu$ SDLA at the bottom of the flight train $40 \mathrm{~m}$ below. The balloon initially ascended up to $20 \mathrm{~km}$ after which it descended slowly after cooling at sunset down to $11.8 \mathrm{~km}$ where the payload was separated. The two instruments performed during the daytime ascent in the troposphere and during the slow night-time descent after 22:00 UTC. Unfortunately, the SAW experienced some technical problems leading to oscillations in the measured frostpoints and no data from this instrument are available for this flight. The $\mu$ SDLA performed well except between 12.8 and $13.4 \mathrm{~km}$ where the data are missing, and between 13.4 and $13.7 \mathrm{~km}$ where suspicious data have been removed. The closest satellite observations available are a HALOE sunrise profile 14 hours before the $\mu$ SDLA record, $475 \mathrm{~km}$ in the SW direction, a SCIAMACHY profile $14 \mathrm{~h}$ after, $883 \mathrm{~km}$ in the SW direction and an AIRS profile $41 \mathrm{~km}$ from the balloon, $6 \mathrm{~h}$ before. The quality flag of AIRS data indicates that the water vapour data were of highest quality.

The profiles of the four instruments between 12 and $20 \mathrm{~km}$ are shown in Fig. 1 left, together with their respective clos- est model profiles in dashed lines of the same colour. Also shown (orange) is the $\mathrm{H}_{2} \mathrm{O}$ saturation mixing ratio calculated from pressure and temperature measurements. The AIRS pressure coordinate was converted in altitude using data from a GPS receiver also carried by the balloon. The percent relative difference of $\mu$ SDLA, HALOE, SCIAMACHY and AIRS in reference to Reprobus is shown in the right panel with a vertical sampling of $1 \mathrm{~km}$ (except for the lower sampling of AIRS).

The $\mu$ SDLA shows a saturated or supersaturated profile in the upper troposphere up to approximately $16 \mathrm{~km}$, with a supersaturation of almost $100 \%$ around the tropopause at $15.5 \mathrm{~km}$ (Marécal et al., 2007). Above $16 \mathrm{~km}, \mu$ SDLA shows a $2 \mathrm{~km}$ thick layer of approximately constant mixing ratio of $3.4-4.5 \mathrm{ppmv}$ up to $18 \mathrm{~km}$, followed by a progressive increase to $6.4 \mathrm{ppmv}$ at $19.5 \mathrm{~km}$. The $10 \mathrm{ppmv}$ peak at the profile top is where the balloon descent velocity is sufficiently low that $\mathrm{H}_{2} \mathrm{O}$ outgassing is likely to be a problem (Durry and Megie, 2000) and should be ignored. Consistent with $\mu$ SDLA, the collocated model profile is saturated at all levels below the tropopause, showing higher moisture than at HALOE, AIRS and SCIAMACHY locations. The two AIRS data points at 13.4 and $15.3 \mathrm{~km}$ are 
Table 3. SF-4. As Table 2 for 24 to 26 February 2004.

\begin{tabular}{lcccrrr}
\hline Instrument & Date and Time UTC & Latitude & Longitude & $\begin{array}{r}\text { Distance to } \\
\mu \text { SDLA }(\mathrm{km})\end{array}$ & $\begin{array}{r}\text { Time difference } \\
(\mathrm{min}) \text { with Reprobus }\end{array}$ & $\begin{array}{r}\text { Distance from } \\
\text { Reprobus }(\mathrm{km})\end{array}$ \\
\hline$\mu$ SDLA \& SAW & 24 Feb. 22:36 & $22.63^{\circ} \mathrm{S}$ & $49.28^{\circ} \mathrm{W}$ & 0 & 6.5 & $\sim 99$ \\
GOMOS & 25 Feb. 03:08 & $16.91^{\circ} \mathrm{S}$ & $53.06^{\circ} \mathrm{W}$ & $\sim 750$ & 6.4 & $\sim 104$ \\
SCIAMACHY & 24 Feb. 12:55 & $29.76^{\circ} \mathrm{S}$ & $53.86^{\circ} \mathrm{W}$ & $\sim 916$ & 3.8 & $\sim 56$ \\
AIRS & 24 Feb. 16:35 & $22.39^{\circ} \mathrm{S}$ & $49.33^{\circ} \mathrm{W}$ & $\sim 27$ & 5.0 & $\sim 100$ \\
MIPAS profile 1 & 26 Feb. 01:00 & $16.96^{\circ} \mathrm{S}$ & $39.42^{\circ} \mathrm{W}$ & $\sim 1210$ & 0.5 & $\sim 102$ \\
MIPAS profile 2 & 26 Feb. 13:47 & $24.19^{\circ} \mathrm{S}$ & $55.38^{\circ} \mathrm{W}$ & $\sim 647$ & 1.6 & $\sim 53$ \\
\hline
\end{tabular}

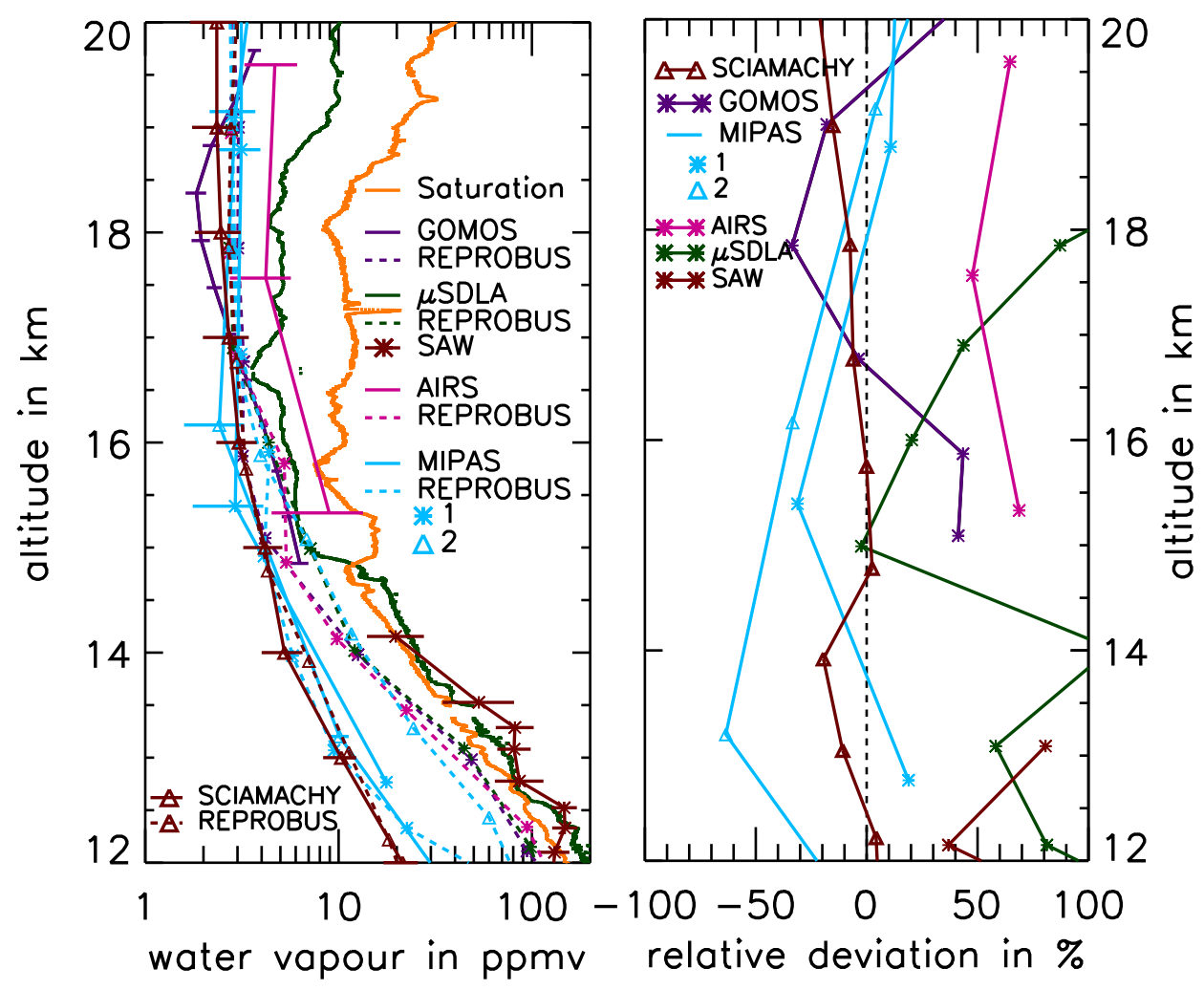

Fig. 2. As Fig. 1 for SF-4 on 24 February: $\mu$ SDLA (green), SAW (brown asterisks), GOMOS (purple), MIPAS (light blue), SCIAMACHY (brown triangles) and AIRS (pink), including errors provided in the data files. Reprobus-ECMWF co-located profiles in same colour but is dashed.

consistent within their error bars with $\mu$ SDLA and slightly wetter compared to ECMWF known to be dry biased at these levels. Though kept in the figure for illustration, the two AIRS data points at higher altitude are little significant being mostly representative of the a priori used in the retrieval. Below $17.5 \mathrm{~km}$, HALOE is dry biased compared to all others, displaying a $2.3 \mathrm{ppmv}$ minimum mixing ratio at about $16.4 \mathrm{~km}$ four times smaller than the saturation mixing ratio at $-79^{\circ} \mathrm{C}$ (the tropopause temperature) and therefore not attributable to local condensation, as reported at very cold $\left(-85^{\circ} \mathrm{C}\right)$ tropopause temperature such as over Northern Australia (Kelly et al., 1993). The SCIAMACHY pro- file is also dry biased compared to AIRS and $\mu$ SDLA. When compared to their respective model profiles, at lower altitudes the $\mu$ SDLA and AIRS measurements are wetter by about 15-40\%. But since ECMWF analyses in 2004 did not permit supersaturation this is not conclusive. Overall, the most significant inference from this comparison is the substantial HALOE dry bias in the upper troposphere reaching $70-80 \%$ around $13 \mathrm{~km}$. Since ECMWF is dry biased by around $40 \%$ at saturation (Luo et al., 2008) and AIRS accurate within $25 \%$, HALOE seems to provide unrealistically low $\mathrm{H}_{2} \mathrm{O}$ mixing ratios at this level. Higher up in the lower stratosphere where AIRS provides little information, 
HALOE and SCIAMACHY are found dry biased by $1.5-$ 2.5 ppmv relative to $\mu$ SDLA.

The second flight, SF-4, was performed in the presence of active local convection (Pommereau et al., 2007). The balloon was launched at 20:03 UTC (17:03 LT) on 24 February 2004 carrying a SAW and the $\mu$ SDLA at the bottom of the flight train. The closest satellite overpasses are those of GOMOS 4.5 hours after the $\mu$ SDLA flight, $750 \mathrm{~km}$ in the N$\mathrm{NW}$, AIRS $6 \mathrm{~h}$ before at $27 \mathrm{~km}$, SCIAMACHY $9.5 \mathrm{~h}$ before at $916 \mathrm{~km}$ in the SW and two MIPAS profiles respectively $26.5 \mathrm{~h}$ after at $1210 \mathrm{~km}$ in the E-NE and 39 hours after at $647 \mathrm{~km}$ in the SW (Table 3). The measurements as well as the saturation mixing ratio and the difference with the model are displayed in Fig. 2.

As in SF-2, $\mu$ SDLA displays supersaturation in the upper troposphere up to $14.8 \mathrm{~km}$, surmounted by a sub-saturated $4 \mathrm{~km}$ thick layer of mixing ratios varying between 4-6 ppmv. $\mu$ SDLA also shows a moist layer above $19 \mathrm{~km}$, which again is close to the balloon float altitude and thus possibly contaminated by outgassing. The relative moistening between 16.5 and $18 \mathrm{~km}$, correlated with a similar increase of $\mathrm{CH}_{4}$, was attributed by Durry et al. (2006) and Nielsen et al. (2007) to the signature of a convective uplift of ice crystals.

The SAW measurements up to $14.2 \mathrm{~km}$ are consistent with those of $\mu$ SDLA within their error bars, and also show saturation or supersaturation in the local convective system reported by the C-Band radar (Pommereau et al., 2007). Both are substantially wetter than the model, $99 \mathrm{~km}$ away from the balloon. Probably because of the presence of the convective system, AIRS measurements ( $27 \mathrm{~km}$ away) are not available below $15 \mathrm{~km}$. There is also a $10-30 \%$ increase in water vapour over the whole altitude range between AIRS versions 4 , only available at the start of this study, and 5 released later, leading to improved agreement with $\mu$ SDLA. GOMOS displays an unrealistic profile with a minimum mixing ratio of $1.8 \mathrm{ppmv}( \pm 0.3 \mathrm{ppmv})$ at $18.4 \mathrm{~km}$, due to the strongly nonuniform response of the detector in the spectral region of water vapour absorption, introducing distortions in the spectra (J.-L. Bertaux, personal communication, 2008). In addition, its error estimates appear unrealistically small.

Although separated by more than $1800 \mathrm{~km}$ and $12 \mathrm{~h}$, the two MIPAS profiles resemble each other whilst the corresponding two Reprobus-ECMWF profiles show larger atmospheric variability in the troposphere. Both MIPAS profiles are dry biased compared to the model around $16 \mathrm{~km}$, in agreement with the findings of Fischer et al. (2008) and Oelhaf et al. (2004). At lower altitude in the upper troposphere, one MIPAS profile is wetter by $20 \%$ but the other is dryer by $70 \%$ compared to the model. A possible explanation for this, noted by Remedios et al. (2007), is the presence of clouds near the threshold value of 1.8 of the cloud index but which are not flagged as clouds in the retrievals. However, as the cloud index for these two profiles were not available, this could not be confirmed. Another possible reason could be an intrusion of dry air from mid-latitudes (e.g.
Durry et al., 2006) not present in the model assimilation. In the stratosphere above $18 \mathrm{~km}$, MIPAS is consistent to within its errors with Reprobus although, the latter is known to be dry biased in the tropics in this altitude range. SCIAMACHY also agrees with the model to within $20 \%$ (its estimated error) over the whole altitude range, suggesting that most of the difference with $\mu$ SDLA in the UT is due to atmospheric variability. Conversely as that was observed in SF-2, above $18 \mathrm{~km}$, SCIAMACHY shows lower water vapour mixing ratios than the model, which is itself known to be dry biased in this altitude range, although this dry bias is still within the estimated uncertainties of SCIAMACHY retrievals $(\sim 30 \%$ in this altitude range).

In summary, the $\mu$ SDLA and SAW in-situ balloon measurements are in agreement in the upper troposphere displaying, as expected in a highly convective region, saturation or supersaturation up to the tropopause. They are wetter by $\sim 20 \%$ than ECMWF, but since supersaturation is not permitted by the model, this difference might be expected. The AIRS measurements in the troposphere, when available, are consistent with those of $\mu$ SDLA, while HALOE and MIPAS are significantly dryer than the in-situ hygrometers and the model. Finally, SCIAMACHY is comparable with modelled profiles at the same location.

Above the tropopause, though consistent with Reprobus, all satellite instruments report about 2 ppmv less water vapour than the $\mu$ SDLA at altitudes where biases due to outgassing are thought unimportant. Finally, the GOMOS appears quite different than the other profiles with seemingly unrealistically small errors.

\subsection{Long duration balloon and satellites collocated pro- files between $10-30^{\circ} \mathrm{S}$}

In order to relate the observations to a common reference, all SAOZ long duration balloon and satellite data available in February-April 2004 in the latitude range $10^{\circ}-30^{\circ} \mathrm{S}$ have been compared to Reprobus-ECMWF co-located profiles within $\pm 1^{\circ}$ in space and less than 7.5 minutes in time of each profile. The advantage of the technique is to limit the comparison only to the cloud free areas accessible to remote sensors (except AIRS). However, since the model is known to be dry biased in the stratosphere, all measurements have also been compared to those of HALOE which is known to be of high accuracy in this region (Randel et al., 2006; Geller et al., 2002; Lelieveld et al., 2007), using the double differencing technique proposed by Hocke et al. (2007).

The numbers of selected profiles of each instrument and the periods of acquisition are summarized in Table 4. For each, a mean profile $\overline{X^{j}}$ was calculated with a vertical sampling of $1 \mathrm{~km}$, except for AIRS which has a vertical sampling of $2 \mathrm{~km}$, following Eq. (1):

$$
\overline{X^{j}}=\frac{1}{n} \sum_{i=1}^{n} X_{i}^{j}
$$


Table 4. Number of selected collocated profiles and periods of observations.

\begin{tabular}{lcl}
\hline Instruments & Numbers of profiles & Periods \\
\hline SAOZ & 50 & 27 Feb-1 Apr \\
SAGE II & 51 & $18-21$ Mar (47); 30 Apr (4) \\
HALOE & 129 & $10-14$ Feb (53); 8-11 Apr (44);23-26 Apr (32) \\
MIPAS & 4244 & 26 Feb-26 Mar \\
GOMOS & 140 & $16-29$ Feb \\
SCIAMACHY & 3433 & 1 Feb-30 Apr \\
AIRS & 19063 & 1 Feb-30 Apr \\
\hline
\end{tabular}

Table 5. Mean difference between SAGE II, SAOZ, MIPAS, GOMOS and SCIAMACHY with HALOE $\mathrm{H}_{2} \mathrm{O}$ profiles in the 20-25 km altitude range.

\begin{tabular}{lccccc}
\hline Instrument & SAGE II & SAOZ & MIPAS & GOMOS & SCIAMACHY \\
\hline Diff. (ppmv) & $-0.04 \pm 0.08$ & $0.51 \pm 0.10$ & $0.38 \pm 0.08$ & $1.57 \pm 1.09$ & $-0.61 \pm 0.15$ \\
Rel. Diff. (\%) & $-1 \pm 3$ & $5 \pm 2$ & $13 \pm 3$ & $53 \pm 35$ & $-21 \pm 5$ \\
\hline
\end{tabular}

where

$\overline{X^{j}}$ is the mean water vapour mixing ratio at altitude $j$,

$X_{i}^{j}$ the water vapour mixing ratio of profile $i$ at altitude $j$ and

$n$ the number of measurements available at altitude $j$

For each, a mean relative difference with Reprobus, Dev, was also calculated using:

$\operatorname{Dev}_{\text {Instr/Reprobus }}^{j}=\frac{\overline{X_{\text {Instr }}^{j}}-\overline{X_{\text {Reprobus }}^{j}}}{\overline{X_{\text {Reprobus }}^{j}}} \times 100$

and finally, a variability, $V$, associated with the mean profile was evaluated using the following equation:

$V^{j}=\frac{\sigma^{j} \times 100}{\overline{X^{j}}}$

where $\sigma^{j}$ is the 1-sigma root-mean-squared difference from the mean profile defined by:

$\sigma^{j}=\sqrt{\frac{1}{n} \sum_{i=1}^{n}\left(X_{i}^{j}-\overline{X^{j}}\right)^{2}}$.

For comparing with HALOE measurements, a relative difference has been calculated by a double differencing technique following Eq. (5):

$$
\begin{aligned}
& \operatorname{Diff}_{\text {Instr/HALOE }}^{j}= \\
& \left(\frac{\overline{X_{\text {Instr }}^{j}}-\overline{X_{\text {Reprobus }_{\text {Instr }}^{j}}}}{\overline{X_{\text {Reprobus }_{\text {Instr }}^{j}}^{j}}}-\frac{\overline{X_{\text {HALOE }}^{j}}-\overline{X_{\text {Reprobus }_{\text {HALOE }}^{j}}}}{\overline{X_{\text {Reprobus }_{\text {HALOE }}^{j}}^{j}}} \times 100\right.
\end{aligned}
$$

Equations (2) and (5) allow the evaluation of the accuracy or possible bias between instruments at a given altitude $j$ while Eq. (3) allows the evaluation of the precision. The results of the statistical comparisons are displayed in Figs. 3, 4 and 5 , and the mean biases between each instrument and HALOE in the 20-25 km altitude range are shown in Table 5.

\subsubsection{HALOE}

More than 100 coincidences are available above $16 \mathrm{~km}$, reducing to 48 at $12 \mathrm{~km}$. Referring to Fig. 3, HALOE and Reprobus-ECMWF both show a constant mixing ratio above $20 \mathrm{~km}$, dryer by $\sim 1 \mathrm{ppmv}(25 \%)$ in the model, but with similar variability $(5-10 \%)$. However, the agreement degrades rapidly at lower altitudes, with HALOE becoming dry biased, displaying a pronounced minimum mixing ratio at about $17 \mathrm{~km}$ which is absent in the model, and an increasing difference at decreasing altitude reaching $-70 \%$ at $12 \mathrm{~km}$. The HALOE variability is also significantly smaller in the troposphere, i.e. $\pm 2.5 \mathrm{ppmv}$ ( $25 \%$ of $10 \mathrm{ppmv}$ ) compared to \pm 22 ppmv ( $55 \%$ of $40 \mathrm{ppmv}$ ) at $12 \mathrm{~km}$ in the model. The bias is similar to that observed between HALOE and SAOZ for ozone (Borchi and Pommereau, 2007) attributed in that case to a growing altitude registration error at altitudes below 21$22 \mathrm{~km}$ in which, after ratioing the measured concentrations by the now overestimated air density, mixing ratios display a minimum at $17 \mathrm{~km}$. The smaller variability observed in the HALOE data in the troposphere is consistent with the optical saturation of spectral lines employed in the $\mathrm{HALOE} \mathrm{H}_{2} \mathrm{O}$ retrieval, as suggested by Grooß et al. (2005), resulting in a loss of sensitivity of the HALOE measurements at lower altitude. 


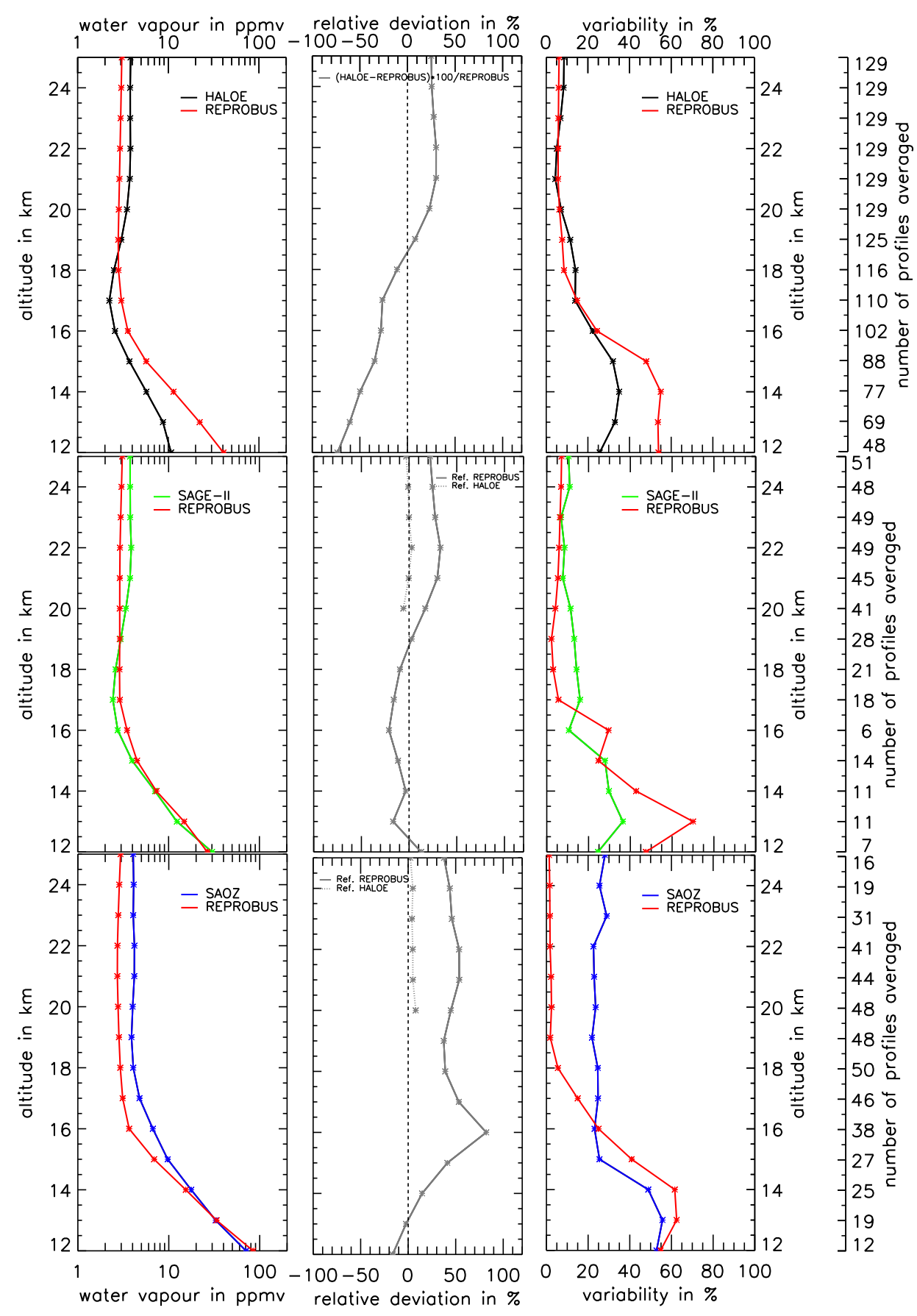

Fig. 3. Comparison between observed and modelled average co-located profiles. From top to bottom: HALOE, SAGE II and SAOZ. Left: mean profiles; Middle: mean relative difference with the model calculated following Eq. (2) and labelled Reprobus in grey, and relative with HALOE in stratosphere using the double differencing technique calculated following Eq. (5), labelled HALOE in dashed grey; Right: variability. Right scale: number of averaged measurements at each level.

\subsubsection{SAGE II}

In total, up to 51 coincidences are available at $25 \mathrm{~km}$, falling to 7 at $12 \mathrm{~km}$ because of the cloud limitation of SAGE II. The data shown here are corresponding to a 1020-nm aerosol extinction not exceeding $3.10^{-4} \mathrm{~km}^{-1}$ as recommended by Thomason et al. (2004), and uncertainty better than 50\% as proposed by Taha et al. (2004). Despite this selection, some dubious profiles remain, for example a profile, excluded from our analysis, showing $18.4 \mathrm{ppmv}$ at $17 \mathrm{~km}$. In 

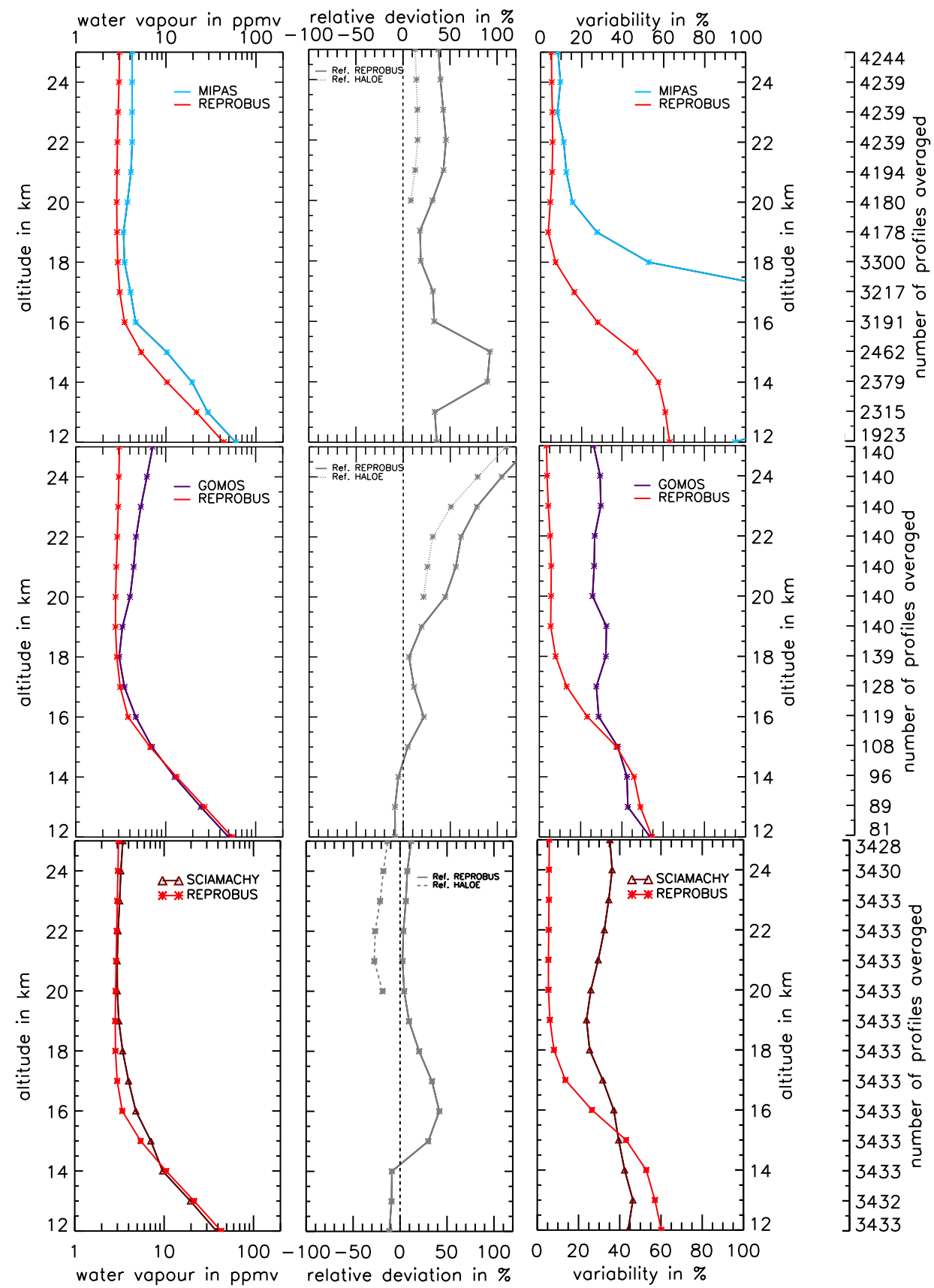

Fig. 4. As Fig. 3, but for MIPAS (top), GOMOS (middle) and SCIAMACHY (bottom).

the stratosphere above $20 \mathrm{~km}$, SAGE II agrees well with HALOE $(-1.3 \%$ using the double differencing technique), although a pronounced minimum is seen in the SAGE II observations at the tropopause (Fig. 3). This level of agreement is perhaps expected given the spectral adjustment made to the SAGE II channel for better consistency with HALOE (Thomason et al., 2004). The only difference at these levels is a little larger $( \pm 7 \%)$ average variability indicative of a slightly lower precision. However, at lower altitudes, in con- trast to HALOE, the SAGE II mean profile better agrees with the model, though also showing less variability. Although the number of collocated profiles is limited below $18 \mathrm{~km}$, this could also indicate a loss of sensitivity in SAGE II due to the many saturated lines in the $940 \mathrm{~nm}$ water vapour absorption band. 

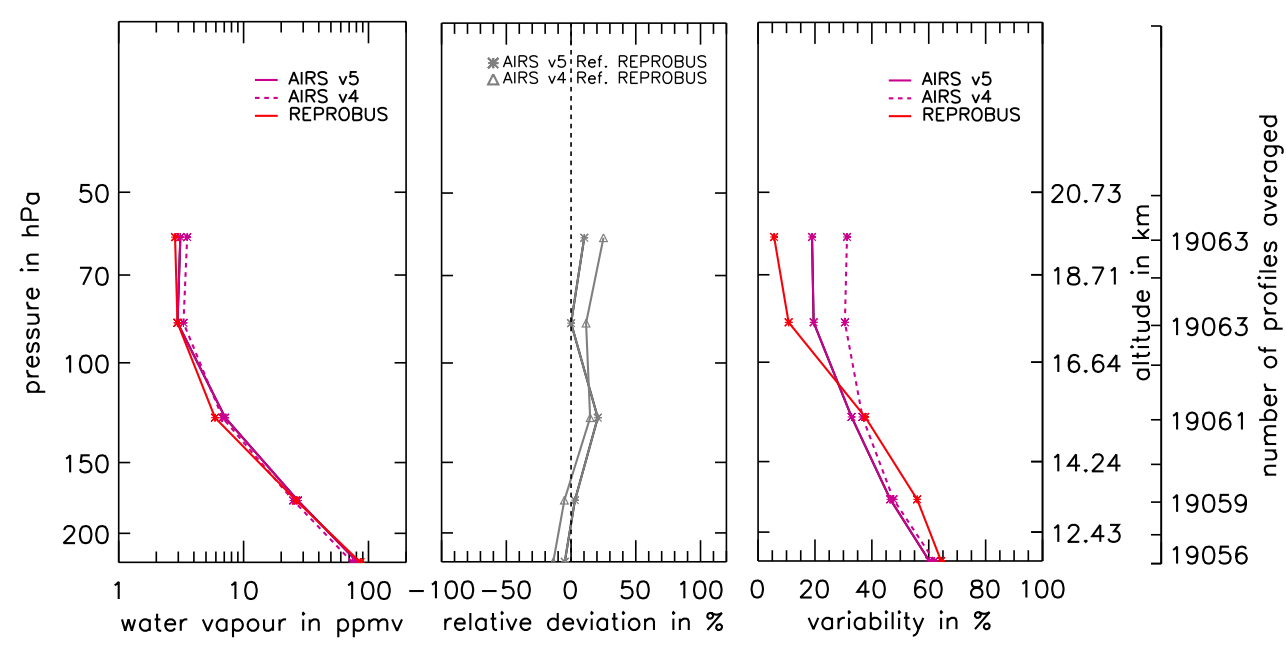

Fig. 5. As Fig. 3 for AIRS v4 and v5.

\subsubsection{SAOZ}

Fifty SAOZ profiles are available at $18 \mathrm{~km}$, falling to 16 at $25 \mathrm{~km}$ which were largely obtained at the beginning of the balloon flight when the balloon was at higher altitude (Borchi and Pommereau, 2007) and to 12 at $12 \mathrm{~km}$ because of the presence of clouds. Compared to Reprobus-ECMWF, SAOZ displays a positive bias of $40-50 \%$ above $20 \mathrm{~km}$ (very similar to that of HALOE), but a larger variability of $20 \%$ around $20 \mathrm{~km}$ increasing to $25-30 \%$ at $25 \mathrm{~km}$, significantly larger than that of the two satellite measurements (Fig. 3). The bias increases to $80 \%$ ( $2.5 \mathrm{ppmv})$ at the tropopause, while at altitudes below $14 \mathrm{~km}, \mathrm{SAOZ}$ agrees quite well with ECMWF, in terms of both magnitude and variability. Below $16 \mathrm{~km}$, the $\mathrm{SAOZ}$ water vapour is derived from the weaker absorption band at $760 \mathrm{~nm}$, far less saturated than the $945 \mathrm{~nm}$ band used at higher altitudes, allowing thus reliable measurements in the upper troposphere.

\subsubsection{MIPAS}

The number of available coincidences exceeds 4000 above $19 \mathrm{~km}$ and is still $\sim 2000$ at $12 \mathrm{~km}$. Above $20 \mathrm{~km}$, MIPAS shows a constant mixing ratio biased high by $40 \%$ (1.2 ppmv) compared to the model and $15 \%(0.4 \mathrm{ppmv})$ compared to HALOE, with a variability of $\sim 10 \%$, slightly higher than that of SAGE II (Fig. 4). At lower altitudes the MIPAS precision degrades rapidly, reaching values larger than $100 \%$ at $17.5 \mathrm{~km}$ as already reported by Oelhaf et al. (2004) and Piccolo and Dudhia (2007), although the average bias compared to the model remains relatively constant throughout. Individual profiles of MIPAS ESA v6.2 operational retrievals must therefore be treated with caution in the troposphere.

\subsubsection{GOMOS}

140 coincidences are available above $19 \mathrm{~km}$, falling to 81 at $12 \mathrm{~km}$. GOMOS shows a positive water vapour gradient above $20 \mathrm{~km}$ in the stratosphere and a variability of $30 \%$, substantially larger than that of other satellite instruments (Fig. 4). The vertical gradient as well as the enhanced noise are attributed to the known problem of non-uniform response of the CCD detector which leads to an inaccurate correction for atmospheric refraction. Below $20 \mathrm{~km}$ there appears to be better agreement between Reprobus and GOMOS profiles and their variability, suggesting that useful measurements might be obtained in this altitude range after correcting for the CCD problem. Meanwhile, caution is recommended when using the water vapour products of the GOMOS v6.0 research algorithm.

\subsubsection{SCIAMACHY}

The number of available coincidences is around 3430 at all altitudes. In the stratosphere, above $20 \mathrm{~km}$, SCIAMACHY shows a very slight positive water vapour gradient with mixing ratios slightly higher than those of Reprobus-ECMWF and around $21 \%$ lower than those of HALOE, with a variability of 30-35\% (Fig. 4). Below $20 \mathrm{~km}$, the shape is similar to that derived from $\mathrm{SAOZ}$ with a positive bias compared to Reprobus of up to $42 \%$ (1.4 ppmv) around $16 \mathrm{~km}$. The maximum relative deviation with respect to the model occurs in the altitude region where the vertical profile of water vapour has maximum curvature. Thus, this difference can in part be explained by the coarser vertical resolution of the SCIAMACHY retrieved $\mathrm{H}_{2} \mathrm{O}$ profiles and the effective interpolation used in the retrieval at the higher spatial gridding. Below $14 \mathrm{~km}$, SCIAMACHY displays a slight dry bias of about $10 \%$ and somewhat smaller variability compared to the model, due 
Table 6. Number of measurements available in February-March 2004 between $10-20^{\circ} \mathrm{S}$.

\begin{tabular}{|c|c|c|c|c|c|c|c|c|}
\hline Altitude (km) & SAOZ & Reprobus & SAGE II & HALOE & MIPAS & GOMOS & SCIAMA-CHY & AIRS \\
\hline 12 & 11 & 5967 & 0 & 6 & 737 & 32 & 736 & $628646(11.7 \mathrm{~km})$ \\
\hline 13 & 18 & 5967 & 0 & 8 & 855 & 36 & 735 & $628589(13.3 \mathrm{~km})$ \\
\hline 14 & 24 & 5967 & 0 & 10 & 859 & 39 & 736 & \\
\hline 15 & 25 & 5967 & 0 & 12 & 931 & 47 & 736 & $628643(15.3 \mathrm{~km})$ \\
\hline 16 & 35 & 5967 & 1 & 15 & 1246 & 53 & 736 & \\
\hline 17 & 42 & 5967 & 1 & 17 & 1248 & 60 & 736 & $628695(17.5 \mathrm{~km})$ \\
\hline 18 & 45 & 5967 & 0 & 19 & 1399 & 72 & 736 & \\
\hline 19 & 43 & 5967 & 1 & 25 & 2029 & 73 & 736 & \\
\hline 20 & 43 & 5967 & 11 & 26 & 2029 & 73 & 736 & $628695(19.6 \mathrm{~km})$ \\
\hline 21 & 39 & 5967 & 14 & 26 & 2048 & 73 & 736 & \\
\hline 22 & 37 & 5967 & 18 & 26 & 2077 & 73 & 736 & \\
\hline 23 & 28 & 5967 & 18 & 26 & 2077 & 73 & 736 & \\
\hline 24 & 18 & 5967 & 17 & 26 & 2077 & 73 & 735 & \\
\hline 25 & 15 & 5967 & 20 & 26 & 2077 & 73 & 735 & \\
\hline
\end{tabular}

Table 7. As Table 6 for $20-30^{\circ} \mathrm{S}$.

\begin{tabular}{cccccccc}
\hline Altitude $(\mathrm{km})$ & Reprobus & SAGE II & HALOE & MIPAS & GOMOS & SCIAMACHY & AIRS \\
\hline 12 & 6363 & 5 & 13 & 1236 & 49 & 1409 & $657345(11.6 \mathrm{~km})$ \\
13 & 6363 & 8 & 19 & 1440 & 53 & 1409 & $657224(13.2 \mathrm{~km})$ \\
14 & 6363 & 9 & 20 & 1472 & 57 & 1409 & \\
15 & 6363 & 11 & 21 & 1589 & 61 & 1409 & $657354(15.3 \mathrm{~km})$ \\
16 & 6363 & 5 & 23 & 1884 & 66 & 1409 & \\
17 & 6363 & 14 & 24 & 1902 & 68 & 1409 & $657427(17.5 \mathrm{~km})$ \\
18 & 6363 & 17 & 25 & 1916 & 68 & 1409 & \\
19 & 6363 & 23 & 26 & 2070 & 68 & 1409 & \\
20 & 6363 & 26 & 27 & 2071 & 68 & 1409 & $657432(19.6 \mathrm{~km})$ \\
21 & 6363 & 27 & 27 & 2071 & 68 & 1409 & \\
22 & 6363 & 27 & 27 & 2075 & 68 & 1409 & \\
23 & 6363 & 27 & 27 & 2075 & 68 & 1409 & \\
24 & 6363 & 27 & 27 & 2075 & 68 & 1407 & \\
25 & 6363 & 27 & 27 & 2075 & 68 & 1408 & \\
\hline
\end{tabular}

to saturation of the strong absorption band selected for the lower stratosphere.

\subsubsection{AIRS}

AIRS water vapour data are available from the surface to $50 \mathrm{hPa}$. Here they are compared to other measurements in the $12-20.7 \mathrm{~km}$ altitude range although they are known to be of limited sensitivity at mixing ratios lower than $10 \mathrm{ppmv}$ in the lower stratosphere (Gettelman et al., 2004). The number of coincidences is about 20000 . For this comparison the Reprobus-ECMWF data have been averaged on the AIRS pressure layers. Over the whole altitude range AIRS v5 and model profiles are in excellent agreement (within 20\%) with AIRS being slightly wet biased at some altitudes (Fig. 5). However it must be recalled that below the tropopause, AIRS measured infrared radiances are assimilated, among other data, in ECMWF (Andersson et al., 2007), and therefore that such consistency might be expected. Below $16 \mathrm{~km}$, the model shows greater variability than AIRS v5 while above, the opposite is true. In the $50-70 \mathrm{hPa}$ pressure layer, the AIRS v5 variability is improved compared to the $\mathrm{v} 4$ version (32\% to 19\%), though it is still larger than the $5.6 \%$ of the model, suggesting an improvement in precision of the new AIRS retrieval algorithm. However, the overall large variability at levels above $100 \mathrm{hPa}$ could be an indication of the loss of sensitivity of the AIRS retrieval at these altitudes and thus of the high contribution of the first guess, even for the v5 retrieval. 

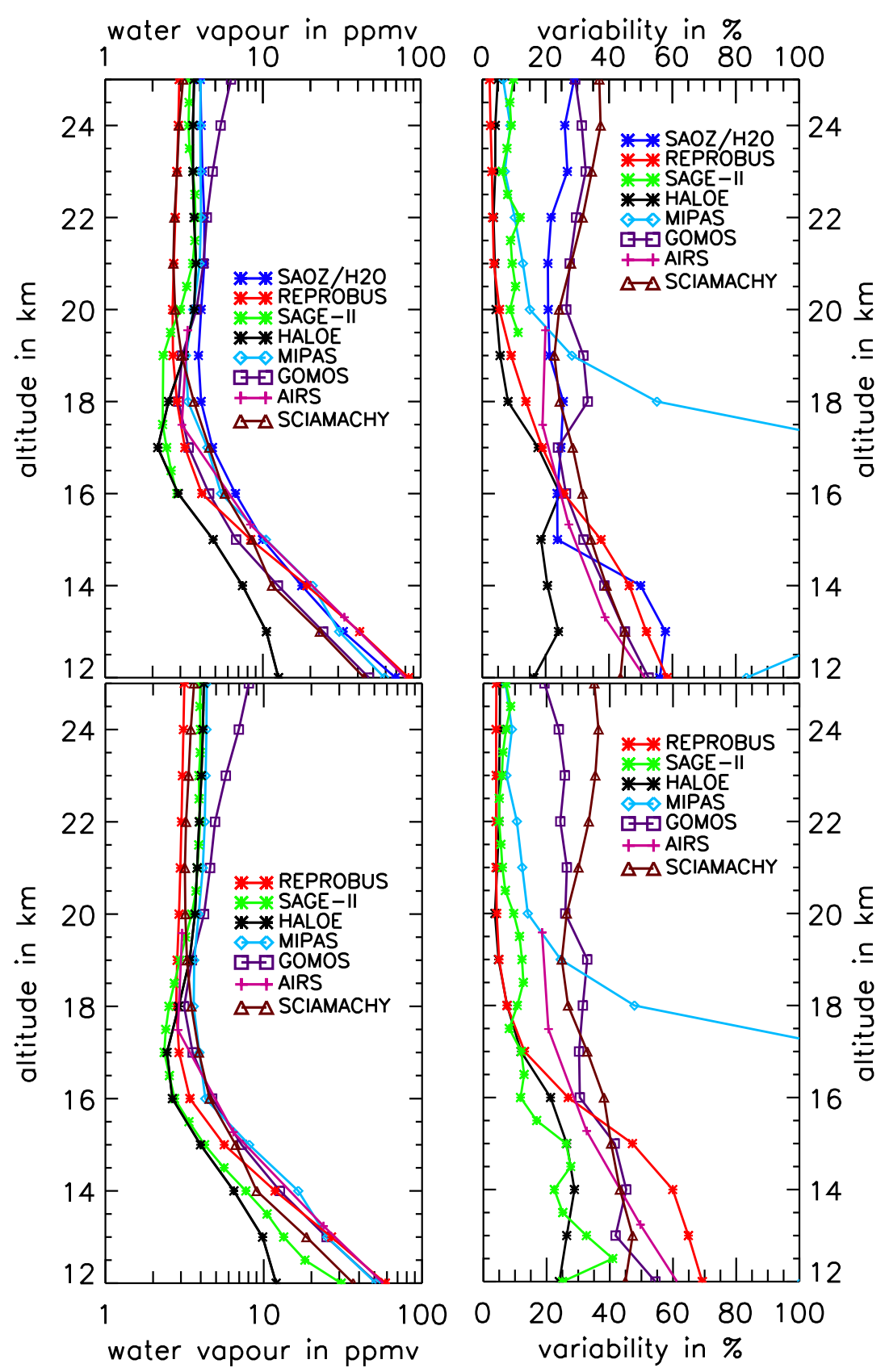

Fig. 6. Zonal mean of all water vapour profiles (left) and variability (right) in February-March 2004 . Top: $10^{\circ}-20^{\circ} \mathrm{S}$, bottom: $20^{\circ}-30^{\circ} \mathrm{S}$.

\subsection{Zonal mean profiles}

Another approach for evaluating the relative performances of all instruments is to compare their zonal mean and associated variability. Figure 6 shows the results of the calculations for the February-March 2004 period between $10^{\circ}-$ $20^{\circ} \mathrm{S}$ (top) and $20^{\circ}-30^{\circ} \mathrm{S}$ (bottom) and Tables 6 and 7 the number of profiles available from each instrument in each case. The main difference with the previous comparison of collocated profiles is that the model includes now cloudy areas not accessible by remote sensing instruments (except for AIRS when combined with AMSU). As expected, water vapour in the upper troposphere is larger in the tropics between $10-20^{\circ} \mathrm{S}$ than in the subtropics between $20-30^{\circ} \mathrm{S}$.

In the stratosphere above $20 \mathrm{~km}$, where there is no cloud, the results are essentially identical to those derived from the comparison of collocated profiles. HALOE, SAGE II, MIPAS and SAOZ are consistent within \pm 0.5 ppmv displaying constant mixing ratio between $20-25 \mathrm{~km}$. Compared to them, Reprobus-ECMWF and SCIAMACHY are low biased by 
about 1 ppmv and 0.5 ppmv respectively and GOMOS show a positive vertical gradient, which as already explained, is thought to be erroneous. Taking the Reprobus variability to be representative of a lower limit for atmospheric variability, the precision of the measurements varies from a value better than $2.5 \%$ for HALOE, to $7 \%$ for SAGE II, $10 \%$ for MIPAS, $20-25 \%$ for SAOZ, $25-30 \%$ for GOMOS and $30-35 \%$ for SCIAMACHY. On most of the measurements, particularly for the large data sets, there is some evidence that the natural variability is somewhat larger than in the model. However, this may be also related to a decrease of precision because of reduced absorption or emission signals at high altitude.

Below $15 \mathrm{~km}$ in the upper troposphere, where they are available (there is only a single SAGE II profile below $20 \mathrm{~km}$ at $10-20^{\circ} \mathrm{S}$ ) HALOE and SAGE II are substantially dry biased compared to all others. Below $18 \mathrm{~km}$, MIPAS also shows an unrealistic statistical variability exceeding $100 \%$. The closest to the model are AIRS, SAOZ and GOMOS in the $20-30^{\circ} \mathrm{S}$ latitude range appearing generally on the dry side of the model below $14 \mathrm{~km}$ and the moist side above. This is consistent with the biases in the ECMWF analyses reported by Ovarlez and Van Velthoven (1997) and Nuret et al. (2008). Below $14 \mathrm{~km}$ where ECMWF is most reliable, the closest is AIRS (again given the assimilation of AIRS radiances into ECMWF analyses, not a surprise). In the 10$20^{\circ} \mathrm{S}$ latitude range SCIAMACHY and GOMOS are low biased compared to the model. GOMOS gives higher mixing ratio in the $20-30^{\circ} \mathrm{S}$ compared to the $10-20^{\circ} \mathrm{S}$ latitude range in contrast to all other instruments. Though the presence of cloudy areas in the model can contribute, there is clear indication of loss of sensitivity of all instruments (lower variability than modelled) particularly HALOE and SAGE II, consistent with the saturation of individual absorption lines not resolved in the measurements. In the TTL between 16 and $20 \mathrm{~km}$ where the AIRS instrument loses sensitivity and the MIPAS precision degrades, HALOE and SAGE II show a minimum $\mathrm{H}_{2} \mathrm{O}$ mixing ratio around $17 \mathrm{~km}$, even in the warmer $20-30^{\circ} \mathrm{S}$ latitude band, which is absent in the model and other measurements. A possible explanation, at least for HALOE, has already been discussed. In this altitude range, the measurements most consistent with the model are those of GOMOS, SCIAMACHY and the SAOZ, showing positive biases of up to $1.3,1.6$ and 2.6 ppmv respectively, with a relatively constant variability of $30 \%$ for GOMOS, 25-35\% for SCIAMACHY and 20-25\% for SAOZ. These differences could partly be due to the method of comparison used. For example the same vertical sampling is used in comparisons when the instruments have not the same vertical resolution, which could lead to errors in regions of large water vapour vertical gradient.

\section{Concluding remarks}

Overall, the measurements performed during the HIBISCUS campaign in February-March 2004 at the southern tropics provide a reasonably consistent picture of the relative precisions and accuracies of balloon and satellite instrument measurements available during the period. In the stratosphere above $20 \mathrm{~km}$, HALOE shows the best precision (2.5\%), followed by SAGE II (7\%), MIPAS (10\%), SAOZ (20-25\%), GOMOS (30\%) and SCIAMACHY (35\%). At $20-25 \mathrm{~km}$, compared to HALOE, SAGE II and SAOZ show insignificant differences, while MIPAS is biased $10 \%$ high and SCIAMACHY 20\% low. However, within their respective accuracies there are no significant biases. The only exception is GOMOS which displays a bias that increases with altitude which is thought to be due to an imperfect refraction correction. Still referenced to HALOE, the Reprobus CTM model forced by ECMWF water vapour at pressures higher than $95 \mathrm{hPa}$, is dry biased by about $20 \%$ (1 ppmv).

At lower altitudes (16-20 km), the measurements show either an increasing variability with decreasing altitude $(10 \%$ for HALOE and SAGE II) or almost constant variability with altitude (25\% for SAOZ, $30 \%$ for SCIAMACHY, $30 \%$ for GOMOS), in accordance with the increasing atmospheric variability at lower altitudes indicated by the ReprobusECMWF model. An exception is MIPAS which displays a sharp degradation of precision at $18 \mathrm{~km}$, at altitudes below which its measurements are unreliable. But biases between instruments also change. HALOE and SAGE II (adjusted to HALOE) show a reduction of water vapour mixing ratio with a minimum at the tropopause not seen by others, including the in situ balloon hygrometer and the model, potentially due to an increasing error in the HALOE altitude registration. Between $16-18 \mathrm{~km}$ where the water vapour concentration shows little spatial variability and where the $\mu$ SDLA balloon measurements are not perturbed by outgassing, the average mixing ratios reported by the remote sensing instruments are substantially lower than the 4-5 ppmv provided by $\mu$ SDLA. The difference with these of the order of -2 ppmv for HALOE and SAGE II, -1 ppmv for SCIAMACHY, MIPAS and GOMOS, and -0.5 ppmv for SAOZ, are exceeding the $10 \%$ uncertainty of the $\mu$ SDLA, implying that systematic errors either in the remote or in the in-situ instruments are larger than quoted.

In the upper troposphere, where the water vapour mixing ratio is highly variable, AIRS v5 appears most consistent (within its 25\% uncertainty) with the in-situ measurements, as well as Reprobus-ECMWF, although it shows lesser variability than the model. Most of the remote measurements show less reliability, losing sensitivity possibly because of absorption line saturation in their spectral range (HALOE, SAGE II and SCIAMACHY) or instrument noise exceeding $100 \%$ (MIPAS). An exception is the SAOZ-balloon, which uses less strongly absorbing $\mathrm{H}_{2} \mathrm{O}$ bands in the troposphere. 
Acknowledgements. The SAGE II and HALOE data have been provided by the NASA Langley Research Centre (NASA-LaRC) and the NASA Langley Radiation and Aerosols Branch, those of MIPAS by the European Space Agency, AIRS by the NASA's Earth-Sun System Division and the Goddard Earth Sciences (GES) Data and Information Services Center (DISC) Distributed Active Archive Center (DAAC) and GOMOS by ACRI, especially G. Barrot and J.-C. Lebrun from the LATMOS. They are all gratefully acknowledged. Balloon operations have been conducted by the Centre National d'Etudes Spatiales (CNES) and the Brazilian Institute for Meteorology (IPMet). The project was supported by the European Regional Development Fund (ERDF) and la Réunion Region (project CycL'Eau), the ENVISAT validation programme ESABC project 713 , the Programme National de Chimie de l'Atmosphère (PNCA) in France and the European Commission within the HIBISCUS (contract EVK2-2001-000111) and SCOUT-O3 (contract 505390-GOCE-CT-2004) projects. The SCIAMACHY level 1 data were provided by ESA. The work at IUP has been funded by DLR Space Agency (Germany), grant 50EE0727, European Commission EC SCOUT-O3, and by the University and State of Bremen. The IUP Bremen group thanks ECMWF for providing the pressure, temperature, and surface elevation information (ECMWF Special Project SPDECDIO). Some data shown here were calculated on German HLRN (High-Performance Computer Center North) and NIC/JUMP (Forschungszentrum Jülich Multiprocessor System). Services and support are gratefully acknowledged. Constructive comments and suggestions for improvements from the four anonymous referees are gratefully acknowledged.

Edited by: P. Haynes

\section{References}

Andersson, E., Hólm, E., Bauer, P., Beljaars, A., Kelly, G. A., McNally, A. P., Simmons, A. J., Thépaut, J.-N., and Tompkins, A. M.: Analysis and forecast impact of the main humidity observing systems, Q. J. Roy. Meteor. Soc., 133, 1473-1485, 2007.

Aumann, H. H., Chahine, M. T., Gautier, C., Goldberg, M. D., Kalnay, E., McMillin, L. M., Revercomb, H., Rosenkranz, P. W., Smith, W. L., Staelin, D. H., Strow, L. L., and Susskind, J.: AIRS/AMSU/HSB on the Aqua mission: Design, science objectives, data products, and processing systems, IEEE T. Geosci. Remote Sens., 41, 253-264, 2003.

Bertaux, J. L., Dalaudier, F., Hauchecorne, A., Chipperfield, M., Fussen, D., Kyrölä, E., Leppelmeier, E., and Roscoe, H.: Envisat: GOMOS-An instrument for global atmosphere ozone monitoring, edited by: Harris R. A., ESA SP-1244, 109 pp., May 2001.

Borchi, F., Pommereau, J.-P., Garnier, A., and Pinharanda, M.: Evaluation of SHADOZ sondes, HALOE and SAGE II ozone profiles at the tropics from SAOZ UV-Vis remote measurements onboard long duration balloons, Atmos. Chem. Phys., 5, 13811397, 2005, http://www.atmos-chem-phys.net/5/1381/2005/.

Borchi, F., and Pommereau, J.-P.: Evaluation of ozonesondes, HALOE, SAGE II and III, Odin-OSIRIS and -SMR, and ENVISAT-GOMOS, -SCIAMACHY and -MIPAS ozone profiles in the tropics from SAOZ long duration balloon measurements in 2003 and 2004, Atmos. Chem. Phys., 7, 2671-2690, 2007, http://www.atmos-chem-phys.net/7/2671/2007/.
Bovensmann, H., Burrows, J. P., Buchwitz, M., Frerick, J., Noël, S., Rozanov, V. V., Chance, K. V., and Goede, A. H. P.: SCIAMACHY - Mission Objectives and Measurement Modes, J. Atmos. Sci., 56, 127-150, 1999.

Buchwitz, M., Rozanov, V. V., and Burrows, J. P.: A correlated-k distribution scheme for overlapping gases suitable for retrieval of atmospheric constituents from moderate resolution radiance measurements in the visible/near-infrared spectral region. J. Geophys. Res., 105, 15247-15261, 2000.

Burrows, J. P., Hölzle E., Goede, A. P. H., Visser, H., and Fricke W.: SCIAMACHY - Scanning Imaging Absorption Spectrometer for Atmospheric Chartography, Acta Astron., 35, 7, 445-451, 1995.

Chiou, E.-W., Thomason, L. W., Burton, S. P., and Michelsen, H. A.: Assessment of the SAGE II version 6.2 water vapor data set through intercomparison with ATMOS/ATLAS-3 measurements, Geophys. Res. Lett., 31, L14101, doi:10.1029/2004GL020071, 2004.

Dhomse, S., Weber, M., and Burrows, J.: The relationship between tropospheric wave forcing and tropical lower stratospheric water vapour, Atmos. Chem. Phys., 8, 471-480, 2008, http://www.atmos-chem-phys.net/8/471/2008/.

Divakarla, M. G., Barnet, C. D., Goldberg, M. D., McMillin, L. M., Maddy, E., Wolf, W., Zhou, L., and Liu, X.: Validation of Atmospheric Infrared Sounder temperature and water vapour retrievals with matched radiosonde measurements and forecasts, J. Geophys. Res., 11, D09S15, doi:10.1029/2005JD006116, 2006.

Durry, G. and Megie, G.: Atmospheric $\mathrm{CH}_{4}$ and $\mathrm{H}_{2} \mathrm{O}$ monitoring with near-infrared InGaAs laser diodes by the SDLA, a balloonborne spectrometer for tropospheric and stratospheric in-situ measurements, Appl. Opt., 38, 7342-7354, 1999.

Durry, G. and Megie, G.: In-situ measurements of $\mathrm{H}_{2} \mathrm{O}$ from a stratospheric balloon by diode laser direct-differential absorption spectroscopy at $1.39 \mu \mathrm{m}$, Appl. Opt., 39, 5601-5608, 2000.

Durry, G., Zeninari, V., Parvitte, B., Le Barbu, T., Lefevre, F., Ovarlez, J., and Gamache, R. R.: Pressure-broadening coefficients and line strengths of $\mathrm{H}_{2} \mathrm{O}$ near $1.39 \mu \mathrm{m}$ : application to the insitu sensing of the middle atmosphere with balloonborne diode lasers, J. Quant. Spectrom. Rad. T., 94, 387-403, 2005.

Durry, G., Huret, N., Hauchecorne, A., Marecal, V., Pommereau, J.-P., Jones, R. L., Held, G., Larsen, N., and Renard, J.-B.: Isentropic advection and convective lifting of water vapour in the UT LS as observed over Brazil $\left(22^{\circ} \mathrm{S}\right)$ in February 2004 by the insitu high-resolution measurements of $\mathrm{H}_{2} \mathrm{O}, \mathrm{CH}_{4}, \mathrm{O}_{3}$ and temperature, Atmos. Chem. Phys. Discuss, 6, 12469-12501, 2006.

ESA, ENVISAT-1 Mission and System Summary, issue 2, 85 p., 1 March 1998. online available at: http://envisat.esa.int/ support-docs/pdf/mis_sys.pdf

Fischer, H., Blom, C., Oelhaf, H., Carli, B., Carlotti, M., Delbouille, L., Ehhallt, D., Flaud, J.-M., Isaksen, I., Lopez-Puertas, M., McElroy, C. T., and Zander, R.: ENVISAT-MIPAS - An instrument for atmospheric chemistry and climate research, ESA Pub. SP-1229, 2000.

Fischer, H., Birk, M., Blom, C., Carli, B., Carlotti, M., Von Clarmann, T., Delbouille, L., Dudhia, A., Ehhalt, D., Endemann, M., Flaud, J.-M., Gessner, R., Kleinert, A., Koopmann, R., Langen, J., Lopez-Puertas, M., Mosner, P., Nett, H., Oelhaf, H., Perron, G., Remedios, J., Ridolfi, M., Stiller, G., and Zander, R.: MIPAS: an instrument for atmospheric and climate research, Atmos. Chem. Phys., 8, 2151-2188, 2008, 
http://www.atmos-chem-phys.net/8/2151/2008/.

Forster, P. M. de F. and Shine, K. P.: Stratospheric water vapour changes as a possible contributor to observed stratospheric cooling, Geophys. Res. Lett., 26, 3309-3312, 1999.

Fueglistaler, S., Bonazzola, M., Haynes, P. H., and Peter, T.: Stratospheric water vapor predicted from the Lagrangian temperature history of air entering the stratosphere in the tropics, J. Geophys. Res., 110, D08107, doi:10.1029/2004JD005516, 2005.

Fueglistaler, S. and Haynes, P. H.: Control of interannual and longer-term variability of stratospheric water vapor, J. Geophys. Res., 110, D24108, doi:10.1029/2005JD006019, 2005.

Geller, M. A., Zhou, X., and Zhang, M. : Simulations of the interannual variability of stratospheric water vapour, J. Atmos. Sci., 59, 1076-1085, 2002.

Gettelman, A., Weinstock, E. M., Fetzer, E. J., Irion, F. W., Eldering, A., Richard, E. C., Rosenlof, K. H., Thompson, T. L., Pittman, J. V., Webster, C. R., and Herman, R. L.: Validation of Aqua satellite data in the upper troposphere and lower stratosphere with in-situ aircraft instruments, Geophys. Res. Lett., 31, L22107, doi:10.1029/2004GL020730, 2004.

Grooß, J.-U. and Russell III, J. M.: Technical note: A stratospheric climatology for $\mathrm{O}_{3}, \mathrm{H}_{2} \mathrm{O}, \mathrm{CH}_{4}, \mathrm{NO}_{\mathrm{x}}, \mathrm{HCl}$ and $\mathrm{HF}$ derived from HALOE measurements, Atmos. Chem. Phys., 5, 2797-2807, 2005, http://www.atmos-chem-phys.net/5/2797/2005/.

Hagan, D. E., Webster C. R., Farmer C. B., May, R. D., Herman, R. L., Weinstock, E. M., Christensen, L. E., Lait, L. R., and Newman, P. A.: Validating AIRS upper atmosphere water vapor retrievals using aircraft and balloon in-situ measurements, Geophys. Res. Lett., 31, L21103, doi:10.1029/2004GL020302, 2004.

Hansford, G. M., Freshwater, R. A., Eden, L., Turnbull, K. F. V., Hadaway, D. E., Ostanin, V. P., and Jones, R. L.: Lightweight dew-/frost-point hygrometer based on a surface-acoustic-wave sensor for balloon-borne atmospheric water vapor profile sounding, Rev. Sci. Instrum., 77, 014502, doi:10.1063/1.2140275, 2006.

Harries, J. E., Russell III, J. M., Tuck, A. F., Gordley, L. L., Purcell, P., Stone, K., Bevilacqua, R. M., Gunson, M., Nedoluha, G., and Traub, W. A.: Validation of measurements of water vapor from the Halogen Occultation Experiment (HALOE), J. Geophys. Res., 101, 10205-10216, 1996.

Hervig, M. E. and McHugh, M. J.: Cirrus detection using HALOE measurements, Geophys. Res. Lett., 26, 719-722, 1999.

Hocke, K., Kämpfer, N., Ruffieux, D., Froidevaux, L., Parrish, A., Boyd, I., Von Clarmann, T., Steck, T., Timofeyev, Y. M., Polyakov, A. V., and Kyrölä, E.: Comparison and synergy of stratospheric ozone measurements by satellite limb sounders and the ground-based microwave radiometer SOMORA, Atmos. Chem. Phys., 7, 4117-4131, 2007,

http://www.atmos-chem-phys.net/7/4117/2007/.

Jensen, E. J., Kinne, S., and Toon, O. B.: Tropical cirrus clouds radiative forcing: Sensitivity studies, Geophys. Res. Lett., 21, 2023-2026, 1994.

Kelly, K. K., Profitt, M. H., Chan, K. R., Loewenstein, M., Podolske, J. R., Strahan, E., Wilson, J. C., and Kley., D.: Water vapor and cloud water measurements over Darwin during the STEP 1987 tropical mission, J. Geophys. Res., 98, 8713-8723, 1993.

Kiefer, M., Von Clarmann, T., Grabowski, U., De Laurentis, M.,
Mantovani, R., Milz, M. and Ridolfi, M.: Characterization of MIPAS elevation pointing, Atmos. Chem. Phys., 7, 1615-1628, 2007, http://www.atmos-chem-phys.net/7/1615/2007/.

Kiehl, J. T. and Trenberth, K. E.: Earth's annual global mean energy budget, B. Am. Meteor. Soc., 78, 197-208, 1997.

Kley, D., Russell III, J. M., and Phillips, C.: SPARC (Stratospheric Processes And their Role in Climate) Assessment of Upper Tropospheric and Stratospheric Water Vapour, WCRP-113, WMO/TD No. 1043, SPARC Report No.2, 2000.

Kneizys, F. X., Shettle, E. P., Abreu, L. W., Chetwynd, J. H., Anderson, G. P., Gallery, W. O., Selby, J. E. A., and Clough, S. A.: Users Guide to LOWTRAN 7. Technical report, Air Force Geophysics Laboratory AFGL, 1986.

Kyrölä, E., Tamminen, J., Leppelmeier, G. W., Sofieva, V., Hassinen, S., Seppälä, A., Verronen, P. T., Bertaux, J.-L., Hauchecorne, A., Dalaudier, F., Fussen, D., Vanhellemont, F., Fanton d'Andon, O., Barrot, G., Mangin, A., Theodore,B., Guirlet, M., Koopman, R., Saavedra de Miguel L., Snoeij, P., Fehr, T., Meijer, Y., and Fraisse, R.: Nighttime ozone profiles in the stratosphere and mesosphere by the Global Ozone Monitoring by Occultation of Stars on Envisat, J. Geophys. Res., 111, D24306, doi:10.1029/2006JD007193, 2006.

Lefèvre, F., Brasseur, G. P., Folkins, I., Smith, A. K., and Simon, P.: Chemistry of the 1991-1992 stratospheric winter: Threedimensional model simulations, J. Geophys. Res., 99, 81838195, 1994.

Lelieveld, J., Brühl, C., Jöckel, P., Steil, B., Crutzen, P. J., Fischer, H., Giorgetta, M. A. Hoor, P., Lawrence, M. G., Sausen, R., and Tost, H.: Stratospheric dryness: model simulations and satellite observations, Atmos. Chem. Phys., 7, 1313-1332, 2007, http://www.atmos-chem-phys.net/7/1313/2007/.

Luo, Z., Kley, D., Johnson, R. H., and Smit, H.: Ten years of measurements of tropical upper-tropospheric water vapor by MOZAIC. Part II: assessing the ECMWF humidity analysis, J. Climate, 21, 1449-1466, doi:10.1175/2007JCLI1887.1, 2008.

Marécal, V., Durry, G., Longo, V., Freitas, S., Rivière, E. D., and Pirre, M.: Mesoscale modelling of water vapour in the tropical UTLS: two case studies from the HIBISCUS campaign, Atmos. Chem. Phys., 7, 1471-1489, 2007, http://www.atmos-chem-phys.net/7/1471/2007/.

Mauldin III, L. E., Zaun, N. H, McCormick, M. P, Guy, J. H., and Vaughan, W. P.: Stratospheric Aerosol and Gas Experiment II Instrument: A Functional Description, Opt. Eng., 24, 307-312, 1985.

Monge-Sanz, B. M., Chipperfield, M. P., Simmons, A. J., and Uppala, S. M.: Mean age of air and transport in a CTM: comparison of different ECMWF analyses. Geophys. Res. Lett., 34, L04801, doi:10.1029/2006GL028515, 2007.

Nielsen, J. K., Larsen, N., Cairon, F., Donfrancesco, Di., G., Rosen, J. M., Durry, G., Hels, G., and Pommereau, J.-P.: Solid particles in the tropical lower stratosphere, Atmos. Chem. Phys., 7, 685695, 2007, http://www.atmos-chem-phys.net/7/685/2007/.

Nuret, M., Lafore, J.-P., Bock, O., Guichard, F., Agusti-Panareda, A., N'Gamini, J.-B., and Redelsperger, J.-L.: Correction of humidity bias for Vaisala RS80-A sondes during the AMMA 2006 observing period, J. Atm. Ocean. Tech., 25, 2152-2158, doi:10.1175/2008JTECHA1103.1, 2008.

Oelhaf, H., Fix, A., Schiller, C., Chance, K., Gurlit, W., Ovarlez, J., Renard, J.-B., Rohs, S., Wetzel, G., Von Clarmann, T., Milz, M., 
Wang, D.-Y., Remedios, J. J., and Waterfall, A. M.: Validation of MIPAS-ENVISAT version 4.61 operational data with balloon and aircraft measurements: $\mathrm{H}_{2}$ 0, ESA SP-562, August 2004.

Oltmans, S. J. and Hofmann D. J.: Increase in lower-stratospheric water vapor at a mid-latitude Northern Hemisphere site from 1981 to 1994 , Nature, 374, 146-149, 1995.

Oltmans, S. J., Vömel, H., Hofmann, D. J., Rosenlof, K. H., and Kley, D.: The increase in stratospheric water vapor from balloonborne, frostpoint hygrometer measurements at Washington, DC and Boulder, Colorado, Geophys. Res. Lett., 27, 3453-3456, 2000 .

Osterman, G. B., Salawitch, R. J., Sen, B., Toon, G. C., Stachnik, R. A., Pickett, H. M., Margitan, J. J., Blavier, J.-F., and Peterson, D. B.: Balloon-borne measurements of stratospheric radicals and their precursors: Implications for the production and loss of ozone, Geophys. Res. Lett., 24, 1107-1110, 1997.

Ovarlez, J. and Van Velthoven, P.: Comparison of Water Vapor Measurements with Data Retrieved from ECMWF Analyses during the POLINAT Experiment, J. Appl. Meteorol., 36, 13291335, 1997.

Parkinson, C. L.: Aqua: An Earth-Observing Satellite Mission to Examine Water and Other Climate Variables, IEEE Trans. Geosci. Remote Sens., 41, 173-183, 2003.

Piccolo, C. and Dudhia, A.: Precision validation of MIPAS-Envisat products, Atmos. Chem. Phys., 7, 1915-1923, 2007, http://www.atmos-chem-phys.net/7/1915/2007/.

Pommereau, J. P. and Piquard, J.: Ozone and nitrogen dioxide vertical distributions by uv-visible solar occultation from balloons, Geophys. Res. Lett., 21, 1227-1230, 1994.

Pommereau, J.-P. and the Hibiscus team: An overview of the HIBISCUS campaign, Atmos. Chem. Phys. Discuss., 7, 2389-2475, 2007, http://www.atmos-chem-physdiscuss.net/7/2389/2007/.

Randel, W. J., Wu, F., Vömel, H., Nedoluha, G. E., and Forster, P.: Decreases in stratospheric water vapour after 2001: Links to changes in the tropical tropopause and the Brewer-Dobson circulation, J. Geophys. Res., 111, D12312, doi:10.1029/2005JD006744, 2006.

Raspollini, P., Belotti, C., Burgess, A., Carli, B., Carlotti, M., Ceccherini, S., Dinelli, B. M., Dudhia, A., Flaud, J.-M., Funke, B., Höpfner, M., López-Puertas, M., Payne, V., Piccolo, C., Remedios, J. J., Ridolfi, M., and Spang, R.: MIPAS level 2 operational analysis, Atmos. Chem. Phys., 6, 5605-5630, 2006,

http://www.atmos-chem-phys.net/6/5605/2006/.

Read, W. G., Lambert, A., Bacmeister, J., Cofield, R. E., Christensen, L. E., Cuddy, D. T., Daffer, W. H., Drouin, B. J., Fetzer, E., Froidevaux, L., Fuller, R., Herman, R., Jarnot. R. F., Jiang, J. H., Jiang, Y. B., Kelly, K., Knosp, B. W., Kovalenko, L. J., Livesey, N. J., Liu, H.-C., Manney, G. L., Pickett, H. M., Pumphrey, H. C., Rosenlof, K. H., Sabounchi, X., Santee, M. L., Schwartz, M. J., Snyder, W. V. Stek, P. C., Su, H., Takacs, L. L., Thurstans, R. P., Vömel, H., Wagner, P. A., Waters, J. W., Webster, C. R., Weinstock, E. M., and Wu, D. L. : Aura Microwave Limb Sounder upper tropospheric and lower stratospheric $\mathrm{H}_{2} \mathrm{O}$ and relative humidity with respect to ice validation, J. Geophys. Res., 112, D24S35, doi:10.1029/2007JD008752, 2007.

Remedios, J. J., Leigh, R. J., Waterfall, A. M., Moore, D. P., Sembhi, H., Parkes, I., J. Greenhough, Chipperfield, M. P., and Hauglustaine, D.: MIPAS reference atmospheres and compar- isons to V4.61/V4.62 MIPAS level 2 geophysical data sets, Atmos. Chem. Phys. Discuss., 7, 9973-10017, 2007,

http://www.atmos-chem-phys-discuss.net/7/9973/2007/.

Rodgers, C. D.: Inverse methods for atmospheric sounding: Theory and practice, Series on Atmospheric, Oceanic and planetary Physics, World Scientific Publishing Co. Ltd., vol. 2, 240 pp., 2000.

Rosenkranz, P. W.: Retrieval of temperature and moistures profiles from AMSU-A AMSU-B measurements, IEEE T. Geosci. Remote Sens., 39, 2429-2435, 2001.

Rosenlof, K. H., and Reid, G.: Trends in the temperature and water vapour content of the tropical lower stratosphere: sea surface connection, J. Geophys. Res. 113, D06107, doi:10.1029/2007JD009109, 2008.

Rothman, L.S., Jaquemart, D., Barbe, A., Benner, D. C., Birk, M., Brown, L. R., Carleer, M. R., Chackerian, C., Chance, K., Coudert, L. H., Dana, V., Devi, V. M., Flaud, J.-M., Gamache, R. R., Goldman, A., Hartmann, J.-M., Jucks, K. W., Maki, A. G., Mandin, J.-Y., Massie, S. T., Orphal, J., Perrin, A., Rinsland, C. P., Smith, M. A. H., Tennyson, J., Tolchenov, R. N., Toth, R. A., Vander Auwera, J., Varanasi, P., and Wagner, G.: The HITRAN 2004 molecular spectroscopic database, J. Quant. Spectrosc. Radiat. T., 96, 139-204, 2005.

Rozanov, A., Rozanov, V., and Burrows, J. P.: A numerical radiative transfer model for a spherical planetary atmosphere: Combined differential-integral approach involving the Picard iterative approximation, J. Quant. Spectrosc. Radiat. Transfer, 69, 491-512, 2001.

Rozanov, A., Rozanov, V., Buchwitz, M., Kokhanovsky, A., and Burrows, J. P.: SCIATRAN 2.0 - A new radiative transfer model for geophysical applications in the $175-2400 \mathrm{~nm}$ spectral region, Adv. Space Res., 36, 1015-1019, doi:10.1016/j.asr.2005.03.012, 2005a.

Rozanov, A., Bovensmann, H., Bracher, A., Hrechanyy, S., Rozanov, V., Sinnhuber, M., Stroh, F., and Burrows, J.: $\mathrm{NO}_{2}$ and $\mathrm{BrO}$ vertical profiles retrieval from SCIAMACHY limb measurements: Sensitivity studies, Adv. Space Res., 36, 846-854, doi:10.1016/j.asr.2005.03.013, 2005 b.

Rozanov, A., Eichmann, K.-U., Von Savigny, C., Bovensmann, H., Burrows, J. P., Von Bargen, A., Doicu, A., Hilgers, S., GodinBeekmann, S., Leblanc, T., and McDermid, I. S., Comparison of the inversion algorithms applied to the ozone vertical profile retrieval from SCIAMACHY limb measurements, Atmos. Chem. Phys., 7, 4763-4779, 2007,

http://www.atmos-chem-phys.net/7/4763/2007/.

Rozanov, A.: SCIATRAN: Radiative transfer model and retrieval software package, http://www.iup.physik.uni-bremen.de/ sciatran, 2008.

Russel III, J. M., Gordley, L. L., Park, J. H., Drayson, S. R., Hesketh, W. D., Cicerone, R. J., Tuck, A. F., Frederick, J. E., Harries, J. E., and Crutzen, P. J.: The HALogen Occultation Experiment, J. Geophys. Res., 98, 10777-10797, 1993.

Scherer, M., Vömel, H., Fueglistaler, S., Oltmans, S. J., and Staehelin, J.: Trends and variability of midlatitude stratospheric water vapour deduced from re-evaluted Boulder balloon series and HALOE, Atmos. Chem. Phys. Discuss., 7, 14511-14542, 2007, http://www.atmos-chem-phys-discuss.net/7/14511/2007/.

Sherwood, C. S. and Dessler., A.: On the control of stratospheric humidity, Geophys. Res. Lett., 16, 2513-2516, 2000. 
Susskind, J., Barnet, C. D., and Blaisdell, J. M.: Retrieval of Atmospheric and Surface Parameters from AIRS/AMSU/HSB Data in the Presence of Clouds, IEEE T. Geosci. Remote Sens., 41, 390409, 2003.

Taha, G., Thomason, L. W., and Burton, S. P.: Comparison of Stratospheric Aerosol and Gas Experiment (SAGE) II version 6.2 water vapor with balloon-borne and space-based instruments, J. Geophys. Res., 109, D18313, doi:10.1029/2004JD004859, 2004.

Tobin, D. C., Revercomb, H. E., Knuteson, R. O., Lesht, B. M., Strow, L. L., Hannon, S. E., Feltz, W. F., Moy, L. A., Fetzer, E. J., and Cress, T. S. : Atmospheric Radiation Measurement site atmospheric state best estimates for Atmospheric Infrared Sounder temperature and water vapour retrieval validation, J. Geophys. Res., 111, D09S14, doi:10.1029/2005JD006103, 2006.

Thomason, L. W., Burton, S. P., Iyer, N., Zawodny, J. M., and Anderson, J.: A revised water vapor product for the Stratospheric Aerosol and Gas Experiment (SAGE) II version 6.2 data set, J. Geophys. Res., 109, D06312, doi:10.1029/2003JD004465, 2004.
Wagner, W., Saul, A., and Pruß, A.: International Equations for the Pressure Along the Melting and Along the Sublimation Curve of Ordinary Water Substance, J. Phys. Chem. Ref. Data, 23, 515527, 1994.

Von Savigny, C., Rozanov, A., Bovensmann, H., Eichmann, K.-U., Noel, S., Rozanov, V. V., Sinnhuber, B.-M.,Weber, M., Burrows, J. P., and Kaiser, J. W.: The ozone hole break-up in September 2002 as seen by SCIAMACHY on ENVISAT, J. Atm. Sci., 62, 721-734, doi:10.1175/JAS-3328.1, 2005.

Wennberg, P.O., Cohen, R. C., Stimpfle, R. M., Koplow, J. P., Anderson, J. G., Salawitch, R. J., Fahey, D. W., Woodbridge, E. L., Keim, E. R., Gao, R. S., Webster, C. R., May, R. D., Toohey, D. W., Avallone, L. M., Proffitt, M. H., Loewenstein, M., Podolske, J. R., Chan, K. R., and Wofsy, S. C.: Removal of stratospheric $\mathrm{O} 3$ by radicals: In-situ measurements of $\mathrm{OH}, \mathrm{HO}_{2}, \mathrm{NO}, \mathrm{NO}_{2}$, ClO and BrO, Science, 266, 398-404, 1994. 